\title{
Nutritional sources of meio- and macrofauna at hydrothermal vents and adjacent areas: natural- abundance radiocarbon and stable isotope analyses
}

\author{
Hidetaka Nomaki ${ }^{1, *}$, Yuki Uejima ${ }^{2}$, Nanako O. Ogawa ${ }^{3}$, Masako Yamane $^{4,7}$, \\ Hiromi K. Watanabe ${ }^{1}$, Reina Senokuchi ${ }^{2}$, Joan M. Bernhard ${ }^{5}$, Tomo Kitahashi ${ }^{6}$, \\ Yosuke Miyairi ${ }^{4}$, Yusuke Yokoyama ${ }^{3,4}$, Naohiko Ohkouchi ${ }^{3}$, Motohiro Shimanaga ${ }^{2}$ \\ ${ }^{1}$ Institute for Extra-cutting-edge Science and Technology Avant-garde Research (X-star), Japan Agency for Marine-Earth \\ Science and Technology (JAMSTEC), Yokosuka 237-0061, Japan \\ ${ }^{2}$ Aitsu Marine Station, Kumamoto University, Kumamoto 861-6102, Japan \\ ${ }^{3}$ Research Institute for Marine Resources Utilization (MRU), Japan Agency for Marine-Earth Science and Technology (JAMSTEC), \\ Yokosuka 237-0061, Japan \\ ${ }^{4}$ Atmosphere and Ocean Research Institute, The University of Tokyo, Chiba 277-8564, Japan \\ ${ }^{5}$ Department of Geology and Geophysics, Woods Hole Oceanographic Institution, Woods Hole, MA 02543, USA \\ ${ }^{6}$ Research Institute for Global Change (RIGC), Japan Agency for Marine-Earth Science and Technology (JAMSTEC), \\ Yokosuka 237-0061, Japan \\ ${ }^{7}$ Present address: Institute for Space-Earth Environmental Research, Nagoya University, Nagoya 464-8601, Japan
}

\begin{abstract}
Deep-sea hydrothermal vents host unique marine ecosystems that rely on organic matter produced by chemoautotrophic microbes together with phytodetritus. Although meiofauna can be abundant at such vents, the small size of meiofauna limits studies on nutritional sources. Here we investigated dietary sources of meio- and macrofauna at hydrothermal vent fields in the western North Pacific using stable carbon and nitrogen isotope ratios $\left(\delta^{13} \mathrm{C}, \delta^{15} \mathrm{~N}\right)$ and natural-abundance radiocarbon $\left(\Delta^{14} \mathrm{C}\right)$. Bacterial mats and Paralvinella spp. (polychaetes) collected from hydrothermal vent chimneys were enriched in ${ }^{13} \mathrm{C}$ (up to $-10 \%$ ) and depleted in ${ }^{14} \mathrm{C}(-700$ to $-580 \%$ ). The $\delta^{13} \mathrm{C}$ and $\Delta^{14} \mathrm{C}$ values of dirivultid copepods, endemic to hydrothermal vent chimneys, were $-11 \%$ and $-661 \%$, respectively, and were similar to the values in the bacterial mats and Paralvinella spp. but distinct from those of nearby non-vent sediments $\left(\delta^{13} \mathrm{C}: \sim-24 \%\right)$ and water-column plankton $\left(\Delta^{14} \mathrm{C}\right.$ : $\sim 40 \%$ o). In contrast, $\delta^{13} \mathrm{C}$ values of nematodes from vent chimneys were similar to those of non-vent sites (ca. $-25 \%$ ). Results suggest that dirivultids relied on vent chimney bacterial mats as their nutritional source, whereas vent nematodes did not obtain significant nutrient amounts from the chemolithoautotrophic microbes. The $\Delta^{14} \mathrm{C}$ values of Neoverruca intermedia (vent barnacle) suggest they gain nutrition from chemoautotrophic microbes, but the source of inorganic carbon was diluted with bottom water much more than those of the Paralvinella habitat, reflecting Neoverruca's more distant distribution from active venting. The combination of stable and radioisotope analyses on hydrothermal vent organisms provides valuable information on their nutritional sources and, hence, their adaptive ecology to chemosynthesis-based ecosystems.
\end{abstract}

KEY WORDS: Meiofauna $\cdot$ Dirivultid copepods $\cdot$ Nematodes $\cdot$ Paralvinella $\cdot$ Neoverruca $\cdot$ Nutrition $\cdot$ Natural-abundance radiocarbon $\cdot$ Stable carbon and nitrogen isotope ratios

\section{INTRODUCTION}

Deep-sea hydrothermal vent ecosystems utilize organic matter $(\mathrm{OM})$ produced by chemoautotrophic

*Corresponding author: nomakih@jamstec.go.jp microbes. Many studies on megafauna, e.g. Riftia tubeworms, Bathymodiolus mussels, and Shinkaia squat lobster, have addressed their nutritional ecologies and symbiotic relationships between host mega-

() The authors 2019. Open Access under Creative Commons by Attribution Licence. Use, distribution and reproduction are unrestricted. Authors and original publication must be credited. 
benthos and microbes (e.g. Cavanaugh et al. 1981, Felbeck 1985, Belkin et al. 1986, Duperron et al. 2006, Watsuji et al. 2014). Those megafauna gain nutrition from the chemoautotrophic microbes that produce OM using energy from the reduction of chemicals contained in hydrothermal vent fluid (e.g. Fisher et al. 1989, Markert et al. 2007). Additionally, some megafauna feed on microbial mats or other organisms living around hydrothermal vents. In general, these megafauna do not possess symbiotic microbes, but gain nutrition from the vent ecosystem, which has an extraordinarily high biomass that can reach 100 s to 1000 s of individuals per $\mathrm{m}^{2}$ (Gebruk et al. 2000, Nakajima et al. 2015). OM originating from phytoplankton also plays a significant role in hydrothermal vent ecosystems (Levin et al. 2016), particularly for filter-feeding species. Hydrothermal vent fluids in the upper bathyal zone may enhance photosynthesis by providing inorganic nutrients such as iron to the photic zone, and resultant photosynthetic carbon inputs to vent ecosystems are proportionally more important than those at deep-sea hydrothermal vents (Sweetman et al. 2013). The production of OM by both chemoautotrophic and photosynthetic pathways makes hydrothermal vents one of the most productive marine habitats which have a further significant influence on surrounding 'background' (nonvent) ecosystems (Levin et al. 2016). Vent megafauna utilize OM either from chemosynthesis or photosynthesis, depending on their feeding habits and mode of symbiosis, if present. Knowledge about the relative contribution of chemoautotrophic vs. photosynthetic carbon to hydrothermal vent and adjacent 'normal' seafloor organisms is crucial because the nutritional sources determine elemental and energy flows through these deep-sea environments.

In contrast to the intensive amount of studies on hydrothermal vent megafauna, vent meiofauna have received less attention, especially regarding their nutrition. 'Meiofauna' refers to a size class rather than taxonomic grouping where meiofaunal organisms typically include those that pass through a $1 \mathrm{~mm}$ mesh sieve but are retained on a $63 \mu \mathrm{m}$ mesh sieve (Giere 2009), noting that deep-sea studies have typically adapted a $32 \mu \mathrm{m}$ mesh as a lower limit (e.g. Gollner et al. 2015b, Schmidt et al. 2018). This abundant deep-sea benthos contributes substantially to deep-sea benthic biomass (e.g. Rex et al. 2006). Among the most abundant deep-sea metazoans, nematodes typically dominate the meiofauna, followed by harpacticoid copepods. Most studies of meiofaunal assemblages at deep-sea hydrothermal vent fields have focused on the East Pacific Rise (e.g.
Dinet et al. 1988, Copley et al. 2007). Vanreusel et al. (2010) reviewed biogeographic data on nematodes associated with chemosynthetic environments in the deep-sea and showed high similarity between vents and adjacent typical, non-vent sediment communities. Similar conclusions were reported from studies on vent meiofaunal communities at the East Pacific Rise (Gollner et al. 2010b) and on nematode communities at the hydrothermal vent field and adjacent non-vent seafloor at the Izu-Ogasawara Arc, western North Pacific (Setoguchi et al. 2014). These faunal similarities suggest low endemism in deep-sea vent meiofaunal species (cf. Gollner et al. 2010b), and that current vent meiofauna invaded from adjacent sediments, presumably related to the absence of a planktonic life stage (cf. Vanreusel et al. 1997). The low endemism of nematodes at hydrothermal vents suggests that most taxa do not solely rely on chemoautotrophic microbial production at vent chimneys.

The family Dirivultidae (Copepoda), an exceptionally abundant meiofaunal taxon at deep-sea hydrothermal vents, are free-living on hard substrate and often co-occur with aggregations of various sessile vent megafauna (Gollner et al. 2010a). Their distribution patterns, their mouthpart morphologies, and observations of partly digested bacteria in their foregut suggest tolerance of a wide range of hydrothermal fluid flux regimes and strong nutritional relationships with chemoautotrophic microbes inhabiting hydrothermal vent chimneys (Dinet et al. 1988, Heptner \& Ivanenko 2002, Gollner et al. 2010a).

Studies of nutritional sources in hydrothermal vent ecosystems (e.g. Rau 1981, Bergquist et al. 2007, Levin et al. 2009, Soto 2009) have utilized stable isotope ratios of carbon $\left(\delta^{13} \mathrm{C}\right)$ and nitrogen $\left(\delta^{15} \mathrm{~N}\right)$, which indicate both carbon source and trophic position (Minagawa \& Wada 1984). Isotopic studies including dirivultid copepods (Limen et al. 2006, 2007, 2008, Gollner et al. 2010a) showed that dirivultid species collected from a high-flow site on active chimneys exhibited distinct carbon isotopic compositions, suggesting utilization of OM produced by chemoautotrophic microbes, while the $\delta^{13} \mathrm{C}$ values of nematodes from a low-flow site at the base of the same chimney did not use such OM (Limen et al. 2007). However, isotopic composition data were obtained from dirivultids and nematodes collected from different habitats, raising questions about whether isotopic differences resulted from different feeding habits or different food availability between habitats. This confusion points to a need for quantitative trophic information regarding co-existing taxon-specific meiofauna from different vent-associated habitats. 
The multiple carbon sources available at hydrothermal vent ecosystems create a need for careful sampling of all possible food sources for appropriate mixing models (Riekenberg et al. 2016). Furthermore, the $\delta^{13} \mathrm{C}$ values of chemoautotrophic microbiota vary as a result of different carbon fixation pathways, such as the reductive tricarboxylic acid cycle (TCA), the Calvin-Benson-Bassham (CBB) cycle, and the reductive pentose phosphate cycle (House et al. 2003, Robinson et al. 2003). These pathways complicate efforts to identify carbon sources of organisms with intermediate $\delta^{13} \mathrm{C}$ values (i.e. $\sim 25$ to $-15 \%$ ), which lie between chemosynthetic organisms with ${ }^{13} \mathrm{C}$ depeleted values such as Bathymodiolus septemdierum $\left(-35 \%\right.$ on average) and organisms with ${ }^{13} \mathrm{C}$ enriched values such as Paralvinella spp. $(-10 \%$ on average) (Yorisue et al. 2012). Intermediate values may result from either a mixed diet of these 2 endmembers or from a phytodetritus diet.

Analysis of natural-abundance radiocarbon $\left(\Delta^{14} \mathrm{C}\right)$ offers a powerful tool for investigating feeding habits of hydrothermal vent organisms in that it can discriminate between carbon sources such as photosynthetic and chemosynthetic OM (Williams et al. 1981). On the one hand, phytodetritus originating from marine phytoplankton exhibits ${ }^{14} \mathrm{C}$ concentrations reflecting those of surface-water dissolved inorganic carbon (DIC). Chemoautotrophic microbes at deep-sea hydrothermal vents, on the other hand, typically exhibit depleted ${ }^{14} \mathrm{C}$ concentrations because they utilize either ${ }^{14} \mathrm{C}$-depleted bottom-water (Stuiver et al. 1983) or ${ }^{14} \mathrm{C}$-depleted $\mathrm{CO}_{2}$ or $\mathrm{CH}_{4}$ from the venting fluid as their inorganic carbon source (Williams et al. 1981). Thus, the $\Delta^{14} \mathrm{C}$ values provide clear evidence of utilization of chemosynthetic OM using carbon derived from hydrothermal fluid or deep-sea bottom water and can discriminate from utilization of phytoplankton. Historically, measurement of $\Delta^{14} \mathrm{C}$ in organisms required considerable sample mass, resulting in few $\Delta^{14} \mathrm{C}$ measurements on hydrothermal vent organisms (clam shells, Turekian et al. 1979; hydrothermal vent bivalves and tubeworms, Williams et al. 1981) and none on small organisms such as meiofauna. However, improvements in sample preparation and measurement procedures during the last 2 decades (Pearson et al. 1998, Yokoyama et al. 2010) now enable application of this method to selected microbial lipid compounds (Pearson et al. 2005) and certain meiofauna that densely colonize hydrothermal vent fields.

In this study, we collected benthic meiofauna (copepods, nematodes, and other taxa) and macrofauna (Neoverruca intermedia and Paralvinella spp.) from a variety of habitats at 3 active hydrothermal vent fields in the western Pacific. The habitats included bacterial mats and detritus on active chimneys, the surface of basal sediments at vent chimneys, surface sediments of non-vent sites inside the calderas, and surface sediments outside calderas. Stable carbon and nitrogen isotopic compositions were measured on isolated organisms and compared with isotopic data of comparable environmental samples. We analysed naturalabundance radiocarbon content in selected organisms and substrates to discriminate the carbon sources between water-column derived photosynthesis and chemosynthesis originating from hydrothermal vent fluids or ambient deep-sea bottom waters.

\section{MATERIALS AND METHODS}

\subsection{Sampling sites}

We sampled 3 submarine volcanos: Myojin Knoll, Myojin-sho submarine caldera, and Bayonnaise Knoll, all located in the Izu-Ogasawara Arc of the western North Pacific (Fig. 1), during a series of R/V 'Natsushima' cruises using the ROV 'Hyper-Dolphin' (Table 1, Uejima et al. 2017, Senokuchi et al. 2018). The Izu-Ogasawara Arc is a $\sim 1200 \mathrm{~km}$ long volcanic arc attributed to the subduction of the Pacific plate beneath the Philippine Sea plate (Honsho et al. 2016). Hydrothermal vent activities were recorded at water depths around 700 to $900 \mathrm{~m}$ at Myojin-sho and Bayonnaise Knoll, while those of Myojin Knoll ranged from 1250 to $1350 \mathrm{~m}$ water depth (Fig. 1, Table 1). Thin volcaniclastic sediments (Iizasa 1993) cover the submarine calderas and differ from the sedimentcovered hydrothermal vent system found in the Okinawa Trough (Kawagucci 2015). As a result, methane and ammonium ion concentrations in the venting fluid at the Izu-Ogasawara Arc area are significantly lower than those of the Okinawa Trough (Kawagucci et al. 2013, Kawagucci 2015). Hydrothermal vent macro- and megafaunal communities in the Izu-Ogasawara Arc area were previously reported in Watanabe et al. (2010).

\subsection{Sampling}

Sediment and detritus sampling was conducted at 4 different types of benthic habitats: outside the caldera as a reference site, in a non-vent field in caldera, at the base of the vent chimney where sediments were deposited, and where OM was attached to the exterior of an active chimney (Table 1, 


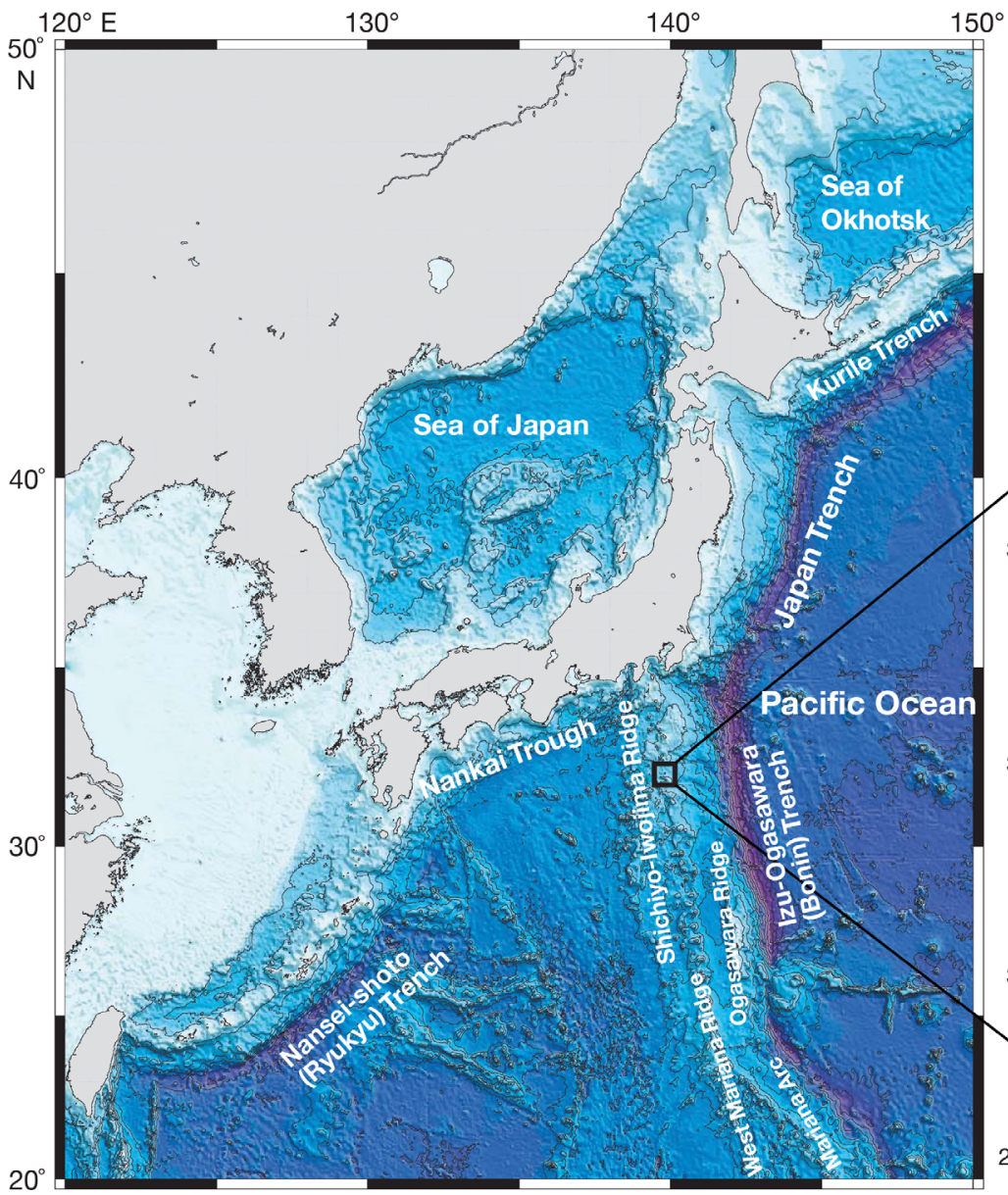

Fig. 1. Bathymetric maps of the sampling area south of Japan. Circles: sampling area for hydrothermal vent chimneys, vent-base sediments, and non-vent sediments at the inside of caldera; triangles: sampling sites for sediments outside the calderas

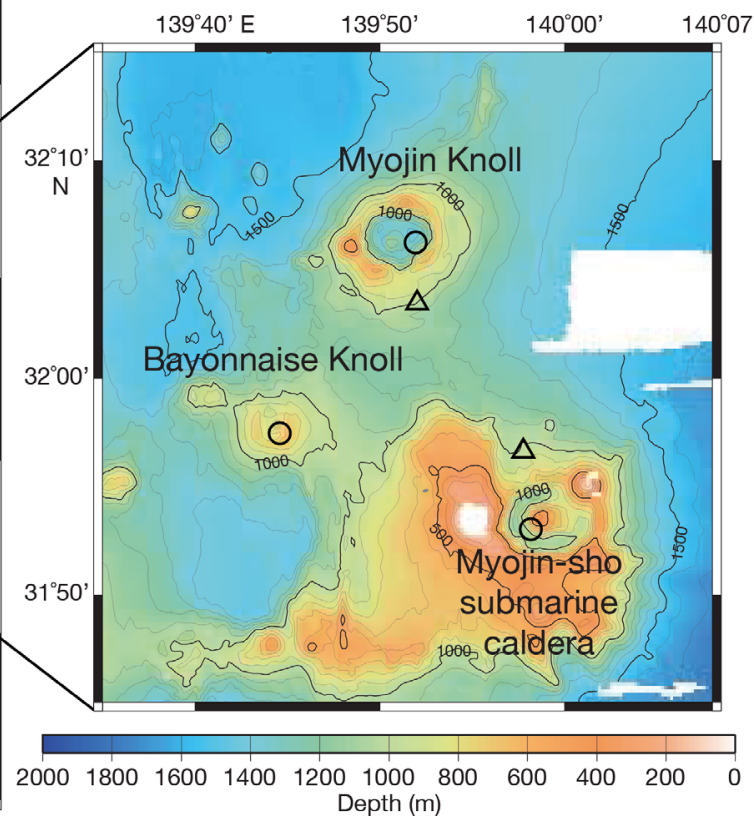

Table 1. Sampling locations, cruise and dive IDs, sampling date, and collected sample types

\begin{tabular}{|c|c|c|c|c|c|c|c|c|c|c|}
\hline $\begin{array}{l}\text { Seamounts } \\
\text { Habitat }\end{array}$ & Cruise ID & Dive \# & Date & Lat. (N) & Long. (E) & Depth (m) & $\begin{array}{l}\text { Sedi- } \\
\text { ment }\end{array}$ & $\begin{array}{l}\mathrm{De}- \\
\text { tritus }\end{array}$ & $\begin{array}{l}\text { Organ- } \\
\text { isms }\end{array}$ & Water \\
\hline \multicolumn{11}{|l|}{ Myojin-sho caldera } \\
\hline \multirow[t]{4}{*}{ Hydrothermal vent area } & NT07-17 & HPD\#749 & Sep 1, 2007 & $31^{\circ} 53.0$ & $139^{\circ} 58.2$ & 883 & & & + & \\
\hline & NT12-10 & HPD\#1374 & Apr 24, 2012 & $31^{\circ} 53.0$ & $139^{\circ} 58.2$ & $809-851$ & + & + & + & \\
\hline & NT13-09 & HPD\#1518 & Apr 23, 2013 & $31^{\circ} 53.0$ & $139^{\circ} 58.2$ & $795-842$ & + & + & + & \\
\hline & NT14-06 & HPD\#1652 & Apr 17, 2014 & $31^{\circ} 53.0$ & $139^{\circ} 58.2$ & $791-853$ & + & + & & \\
\hline Non-vent site in caldera & NT12-10 & HPD\#1374 & Apr 24, 2012 & $31^{\circ} 53.0$ & $139^{\circ} 58.0$ & 994 & + & & & \\
\hline Outside of caldera & NT13-09 & HPD\#1517 & Apr 23, 2013 & $31^{\circ} 56.8$ & $139^{\circ} 57.6$ & $1000-1002$ & + & & & \\
\hline Water column & NT13-09 & HPD\#1516 & Apr 22, 2013 & $31^{\circ} 53.0$ & $139^{\circ} 58.0$ & 300 & & & + & \\
\hline \multicolumn{11}{|l|}{ Myojin Knoll } \\
\hline \multirow[t]{4}{*}{ Hydrothermal vent area } & NT12-10 & HPD\#1377 & Apr 28, 2012 & $32^{\circ} 06.2$ & $139^{\circ} 52.1$ & $1249-1324$ & + & + & + & \\
\hline & NT13-09 & HPD\#1519 & Apr 25, 2013 & $32^{\circ} 06.2$ & $139^{\circ} 52.1$ & $1251-1307$ & + & + & & \\
\hline & NT13-09 & HPD\#1520 & Apr 27, 2013 & $32^{\circ} 06.2$ & $139^{\circ} 52.1$ & $1250-1268$ & + & + & & \\
\hline & KM16-07 & KM-ROV\#20 & Sep 3, 2016 & $32^{\circ} 06.3$ & $139^{\circ} 52.1$ & 1325 & & & & + \\
\hline \multirow{3}{*}{ Non-vent site in caldera } & NT12-10 & HPD\#1377 & Apr 28, 2012 & $32^{\circ} 06.3$ & $139^{\circ} 52.0$ & 1399 & + & & & \\
\hline & NT13-09 & HPD\#1520 & Apr 27, 2013 & $32^{\circ} 06.3$ & $139^{\circ} 52.1$ & 1354 & + & & & \\
\hline & KM16-07 & KM-ROV\#20 & Sep 3, 2016 & $32^{\circ} 06.3$ & $139^{\circ} 58.2$ & 1334 & & & & + \\
\hline Outside of caldera & NT12-10 & HPD\#1378 & Apr 29, 2012 & $32^{\circ} 03.4$ & $139^{\circ} 52.0$ & 998 & + & & + & \\
\hline \multicolumn{11}{|l|}{ Bayonnaise Knoll } \\
\hline \multirow[t]{3}{*}{ Hydrothermal vent area } & NT14-06 & HPD\#1647 & Apr 12, 2014 & $31^{\circ} 57.4$ & $139^{\circ} 44.7$ & $742-778$ & + & + & + & \\
\hline & NT14-06 & HPD\#1648 & Apr 15, 2014 & $31^{\circ} 57.4$ & $139^{\circ} 44.7$ & $777-781$ & + & + & & \\
\hline & NT14-06 & HPD\#1649 & Apr 15, 2014 & $31^{\circ} 57.4$ & $139^{\circ} 44.7$ & $772-779$ & + & + & + & \\
\hline \multirow[t]{3}{*}{ Non-vent site in caldera } & NT14-06 & HPD\#1647 & Apr 12, 2014 & $31^{\circ} 57.5$ & $139^{\circ} 44.6$ & 831 & + & & & \\
\hline & NT14-06 & HPD\#1648 & Apr 15, 2014 & $31^{\circ} 57.5$ & $139^{\circ} 44.6$ & 832 & + & & & \\
\hline & NT14-06 & HPD\#1649 & Apr 15, 2014 & $31^{\circ} 57.5$ & $139^{\circ} 44.6$ & 831 & + & & + & \\
\hline
\end{tabular}


Table S1 in the Supplement at www.int-res.com/ articles/suppl/m622p049_supp.xlsx). Meio- and macrofauna for the isotope measurements were isolated from these sediment and detritus samples (Tables S2 \& S3). Water-column zooplankton, bottom water and hydrothermal vent fluids were also collected at Myojin-sho and Myojin Knoll for natural-abundance radiocarbon analyses (Table 1, Table $\mathrm{S} 4$ ).

Two different types of push corers were used to obtain quantitative sediment samples (H-type: inner diameter $82 \mathrm{~mm}$; S-type: inner diameter $50 \mathrm{~mm}$; Table S1). In cases where sediment layers were too thin or too coarse for collection with push corers, we used an M-type sediment sampler to collect the surface $\sim 3 \mathrm{~cm}$ of sediments via scooping. On board, core samples were sliced horizontally into 4 layers $(0-1$, $1-2,2-3$, and $3-5 \mathrm{~cm}$ ). A small amount (ca. $2 \mathrm{ml}$ ) of sediment or bacterial mat was collected from each sediment slice or suction sample for determination of total organic carbon (TOC), total nitrogen (TN) concentration, and isotopic compositions. These aliquots were placed into pre-combusted $20 \mathrm{ml}$ glass bottles and kept frozen at $-20^{\circ} \mathrm{C}$. The remaining sediment slices or suction samples were split in half using a plankton splitter (RIGO). One half of each sample was immediately fixed and preserved in $5 \%$ formalin buffered with seawater for taxonomic study. After removing excess seawater, the other half was preserved with $99.5 \%$ EtOH for molecular phylogenetic study and isotopic composition measurements. Previous studies report that ethanol preservation sometimes causes a shift in $\delta^{13} \mathrm{C}$ values, typically within a few \%o (e.g. Enge et al. 2018). However, these isotopic shifts are relatively small compared to $\delta^{13} \mathrm{C}$ variation in hydrothermal vent ecosystems (typically $\sim 30 \%$ ) (Bell et al. 2016). Visible large agglutinated foraminifera (presumably Pelosina sp," hereafter Pelosina) on surface sediments at the base of the $20 \mathrm{~m}$ high chimney at Myojin Knoll were isolated before sediment slicing and preserved at $-80^{\circ} \mathrm{C}$.

Bacterial mats, detritus, and meiofauna from the vent chimney were collected with a suction sampler (Fig. 2) with exchangeable sample containers equipped with a $30 \mu \mathrm{m}$ mesh at the outlet. Detritus was collected from colonies of Paralvinella spp., which include Paralvinella hessleri and Paralvinella sp. (N. Jimi pers. comm.), on the surfaces of active chimneys of Myojin Knoll and Myojin-sho. These colonies typically occurred in close proximity to venting locations with high water temperatures (Watanabe \& Kojima 2015). One of the Paralvinella colonies (sample ID S4a in Table S2) was considerably smaller $(\sim 15 \mathrm{~cm}$ in diameter) than the others (typically larger than $30 \mathrm{~cm}$ in diameter) and suction sampling may have included some surrounding detritus as a result of difficulties manipulating the suction sampler. Other Paralvinella colonies were sufficiently large to avoid potential contamination (Fig. 2D). At some chimneys, we took suction samples from colonies of Neoverruca intermedia, a vent barnacle that occurs $10 \mathrm{~s}$ of $\mathrm{cm}$ away from active venting. We found no obvious macrofaunal colonies at Bayonnaise Knoll, therefore, we collected white bacterial mats around the active vent of some chimneys (Table S2).

We also conducted suction sampling in the water column (depth $300 \mathrm{~m}$ ) to collect plankton and nekton that rely solely on photosynthetic OM. We filtered seawater through a $30 \mu \mathrm{m}$ mesh and fixed the material retained on the mesh with $99.9 \% \mathrm{EtOH}$. Among these water-column samples, we removed Decapoda (shrimp) and Chaetognatha for $\Delta^{14} \mathrm{C}$ analyses (Table S4).

In the laboratory on land (Kumamoto University), we isolated metazoan meio-macrofaunal specimens from EtOH-fixed detritus samples and from 0-1 cm layer sediments, then transferred them to flat-bottomed petri dishes. We then picked them at random using tweezers or an Irwin loop under a binocular stereoscopic microscope until we obtained enough biomass for isotopic analyses (Tables S3 \& S4). We identified specimens to higher taxonomic levels (i.e. nematodes, isopods, small polychaetes) for this analysis according to Higgins \& Thiel (1988) and Giere (2009). We subdivided copepods to Dirivultidae (Siphonostomatoida), a typical vent group of relatively large size and characteristic morphology, and the other small copepods (mainly harpacticoids) using taxonomic keys prepared by Boxshall \& Halsey (2004) and Gollner et al. (2010a). Very recently, the most abundant species of Dirivultidae in this area was discovered to be new to science and was described as Stygiopontius senokuchiae (Uyeno et al. 2018); adult females of this species were sorted for ${ }^{14} \mathrm{C}$ analysis (Table S3). Most of the dirivultid samples utilized for our stable isotope analyses included this dominant species, although we conservatively describe those samples as 'Dirivultidae'. Specimens of Paralvinella spp. were also sorted based on Rouse \& Pleijel (2001), although we report them as Paralvinella spp. here as mentioned above.

Bottom seawater and hydrothermal vent fluid were collected using a Perista pump sampler at Myojin Knoll for $\Delta^{14} \mathrm{C}$ analyses of DIC (Table 1). We collected bottom seawater $\sim 20 \mathrm{~m}$ away from the closest venting field with a 51 Niskin bottle attached to the Kaimei-ROV. We also collected hydrothermal vent 

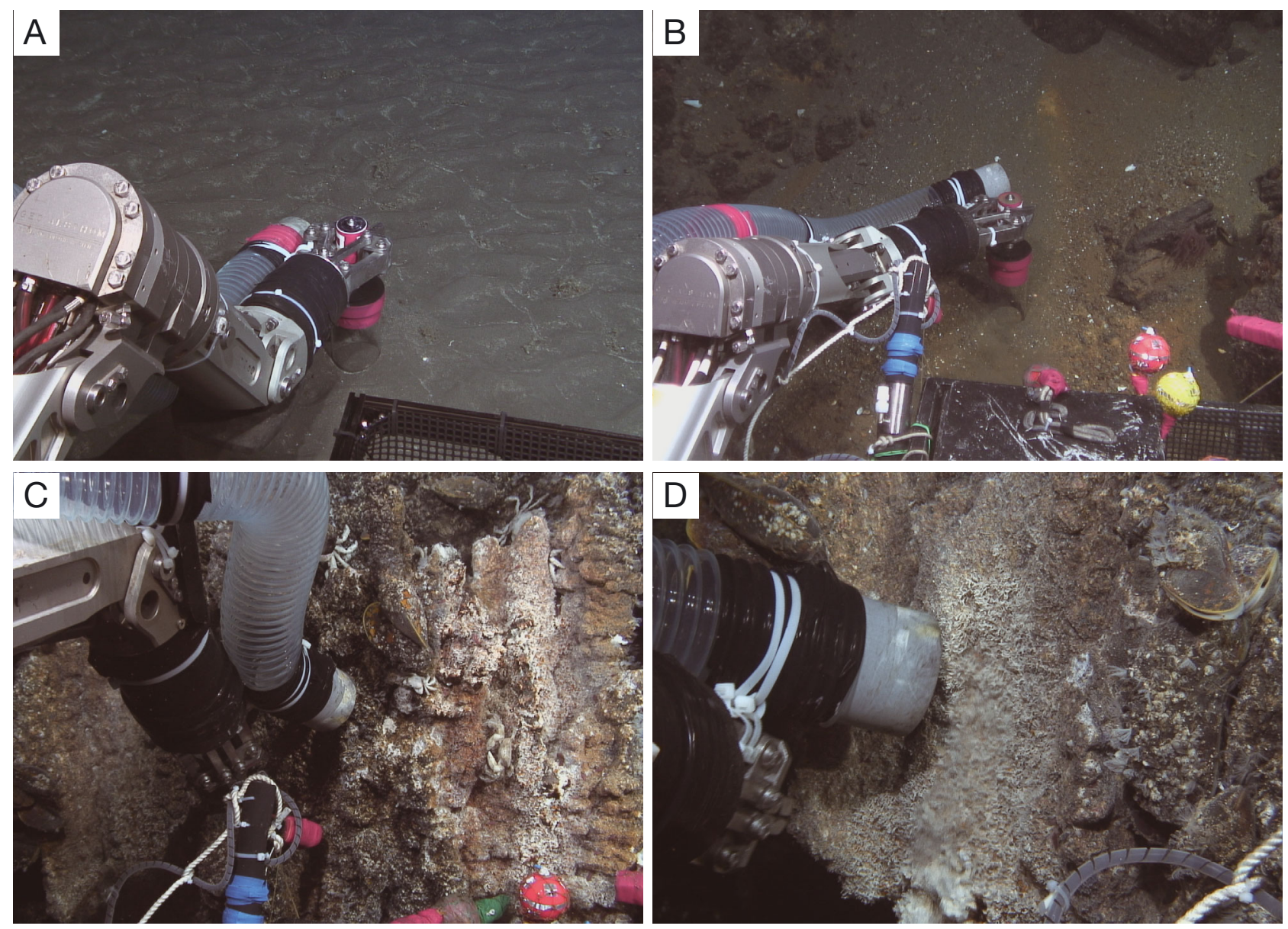

Fig. 2. Photographs showing $(A, B)$ push core and $(C, D)$ suction samplings using the ROV 'Hyper-Dolphin'. (A) Coring outside Myojin-sho caldera, (B) coring the base of a Myojin Knoll hydrothermal vent chimney, and suction sampling in a (C) Neoverruca intermedia colony and (D) Paralvinella colony

fluid via pumping through titanium and silicon tubing into a polyethylene container. On board, we gently subsampled approximately $100 \mathrm{ml}$ of the bottom seawater and vent fluid into gas-tight bottles and preserved them by adding saturated $\mathrm{HgCl}_{2}$ solution. We measured the stable carbon isotopic composition of DIC with a stable isotope mass spectrometer (IsoPrime, GV Instruments) based on the method described by Nomaki et al. (2011).

\subsection{Analyses of TOC, TN, and their isotopic compositions}

The sediment, bacterial mat, detritus, and agglutinated foraminiferal samples used for TOC concentrations, TN concentrations, and their carbon and nitrogen isotopic compositions $\left(\delta^{13} \mathrm{C}, \delta^{15} \mathrm{~N}\right)$ were freeze-dried, powdered, and weighed into precleaned silver capsules (Nomaki et al. 2008, Ogawa et al. 2010). We decalcified the samples with $2 \mathrm{M}$ $\mathrm{HCl}$, followed by drying on a hotplate at $60^{\circ} \mathrm{C}$. We sealed dried silver capsules containing decalcified samples into pre-cleaned tin capsules prior to isotopic analysis. We placed metazoan meiofaunal and macrofaunal (Paralvinella spp. and Neoverruca intermedia) samples directly into pre-cleaned tin capsules and dried at $60^{\circ} \mathrm{C}$ to remove water and $\mathrm{EtOH}$ to determine their dry weight. After weighing, they were decalcified with $0.1 \mathrm{M} \mathrm{HCl}$ and completely dried again, and then sealed with pre-cleaned forceps.

We determined carbon and nitrogen isotopic compositions along with TOC and TN content of sediment and detritus samples using an isotope ratio mass spectrometer coupled to an elemental analyzer (Flash EA1112-DELTA V Advantage ConFloIV System, Thermo Fisher Scientific). The isotope ratios were expressed by delta-notation as $\delta \mathrm{X}=\left[\left(R_{\text {sample }} /\right.\right.$ $\left.\left(R_{\text {standard }}\right)-1\right] \times 1000$, where $\mathrm{X}$ is ${ }^{13} \mathrm{C}$ or ${ }^{15} \mathrm{~N}$ and $(R$ is the ratio of ${ }^{13} \mathrm{C}:{ }^{12} \mathrm{C}$ or ${ }^{15} \mathrm{~N}:{ }^{14} \mathrm{~N}$. Vienna Pee Dee 
Belemnite (VPDB) for carbon and atmospheric $\mathrm{N}_{2}$ (AIR) for nitrogen were used as standards. We measured working standards with known carbon and nitrogen concentrations and their isotopic compositions every 10 to 15 samples. For quantification of TOC and TN, we used acetanilide as the working standard. The analytical errors (SE) for the standard TOC and TN concentrations were $\pm 0.3 \%$. For the $\delta^{13} \mathrm{C}$ measurements, we used alanine $\left(\delta^{13} \mathrm{C}:-19.6 \pm\right.$ $0.2 \%)$, histidine $\left(\delta^{13} \mathrm{C}:-10.7 \pm 0.2 \%\right)$, and glycine $\left(\delta^{13} \mathrm{C}:-33.8 \pm 0.2 \%\right.$ o) as working standards. For $\delta^{15} \mathrm{~N}$ analyses, we used 2 different alanine working standards with different nitrogen isotopic compositions $\left(\delta^{15} \mathrm{~N}=1.6 \pm 0.2 \%\right.$ and $10.1 \pm 0.2 \%$ o). Analytical errors for the $\delta^{13} \mathrm{C}$ and $\delta^{15} \mathrm{~N}$ standards were both $< \pm 0.15 \%$.

Analyses of meio- and macrofaunal samples were determined using an isotope ratio monitoring mass spectrometer (Delta plus XP, Thermo Finnigan) connected to an elemental analyzer (FlashEA1112, Thermo Finnigan) through a continuous flow interface (ConFloIII, Thermo Finnigan). We used an organic standard of tyrosine $\left(B G-T ; \delta^{13} \mathrm{C}:-20.83 \%, \delta^{15} \mathrm{~N}: 8.74 \%\right.$; Tayasu et al. 2011) as a working standard. Analytical errors for the standards of $\delta^{13} \mathrm{C}$ and $\delta^{15} \mathrm{~N}$ were \pm $0.12 \%$ (SD, $1 \sigma)$ and $\pm 0.33 \%$ o (SD, $1 \sigma)$, respectively.

Here, we cite the isotopic compositions of sediment data obtained from Myojin Knoll collected in 2008 (cruise ID NT08-07) for comparison (Setoguchi et al. 2014).

\section{4. ${ }^{14} \mathrm{C}$ analysis of organisms, bacterial mats, and seawater}

In order to discriminate the contribution of carbon derived from hydrothermal vents versus sinking OM from the surface ocean, we examined the naturalabundance radiocarbon of Stygiopontius senokuchiae (Dirivultidae), Neoverruca intermedia, Paralvinella spp., bacterial mats of Paralvinella spp. from active chimneys, and zooplankton samples (Decapoda and Chaetognatha) collected from the water column.

We placed samples in pre-combusted glass cups and dried them on a hotplate to remove water and EtOH, decalcified with $0.1 \mathrm{M} \mathrm{HCl}$, and completely dried them again. The samples were further graphitised according to the modified methods of Yokoyama et al. (2010). Briefly, dried samples (90 to $617 \mu \mathrm{g}$ ) were combusted in an evacuated quartz tube with copper oxide at $500^{\circ} \mathrm{C}$ for $30 \mathrm{~min}$ and at $850^{\circ} \mathrm{C}$ for $2 \mathrm{~h}$. The $\mathrm{CO}_{2}$ gas was cryogenically purified in a vacuum line and reduced to graphite with hydrogen and an iron catalyst at $550^{\circ} \mathrm{C}$ for $10 \mathrm{~h}$. We measured the $\Delta^{14} \mathrm{C}$ values with an accelerator mass spectrometer (AMS) at the Atmosphere and Ocean Research Institute (AMS lab code YAUT). The $\Delta{ }^{14} \mathrm{C}(\%)$ value was defined as follows (Stuiver \& Polach 1977):

$$
\Delta^{14} \mathrm{C}(\%)=\delta^{14} \mathrm{C}-2\left(\delta^{13} \mathrm{C}+25\right)\left(1+\delta^{14} \mathrm{C} / 1000\right)
$$

The $\Delta{ }^{14} \mathrm{C}$ value of the international standard (oxalic acid) takes into account radioactive decay since 1950 (Stuiver \& Polach 1977). The 1 sigma analytical precision of the $\Delta^{14} \mathrm{C}$ measurements was within $6 \%$ (Table S4).

\section{RESULTS}

\subsection{TOC, TN, $\delta^{13} \mathrm{C}$, and $\delta^{15} \mathrm{~N}$ profiles in sediments}

TOC and TN concentration profiles differed between sediment collected from the active hydrothermal vent and non-vent areas (Fig. 3, Table S1). Two cores collected at the base of the chimney showed obvious surface peaks in TOC and TN concentrations, which were roughly 3 to 4 times higher in the surface layer $(0$ to $1 \mathrm{~cm})$ than in deeper layers (Table S1, Fig. 3C,E). Below $1 \mathrm{~cm}$ depth in sediments, TOC concentrations were largely comparable between non-vent and vent-base sediments at Myojin Knoll, but vent sediment TOC values were nonetheless higher than non-vent sediments TOC at Bayonnaise Knoll, though these numbers represent single core results at both sites. $\mathrm{C} / \mathrm{N}$ ratios showed no obvious vertical trends both in non-vent and vent-base sediments, however, vent-base sediments at Myojin Knoll exhibited lower C/N ratios than non-vent sediments through the analyzed depth intervals (Fig. 3D). We found no obvious vertical trend in $\delta^{13} \mathrm{C}$ and $\delta^{15} \mathrm{~N}$ in either non-vent and chimney-base samples (Table S1), except for in cores showing obvious surface TOC peaks (Fig. 3). These cores exhibited ${ }^{13} \mathrm{C}$ depleted values $(-27.2$ and $-25.8 \%$ ) in the surface $\mathrm{cm}$ compared to deeper layers ( -24.7 to $-21.4 \%$ ).

\subsection{Meiofaunal, macrofaunal, and habitat $\delta^{13} \mathrm{C}$ and $\delta^{15} \mathrm{~N}$ values}

We plotted the meio- and macrofaunal $\delta^{13} \mathrm{C}$ and $\delta^{15} \mathrm{~N}$ values against those from the surface $0-1 \mathrm{~cm}$ or bulk surface sediment values, where we obtained meiofaunal samples, and excluded values below the surface layer (Table S1) from dual isotope plots (Fig. 4). 

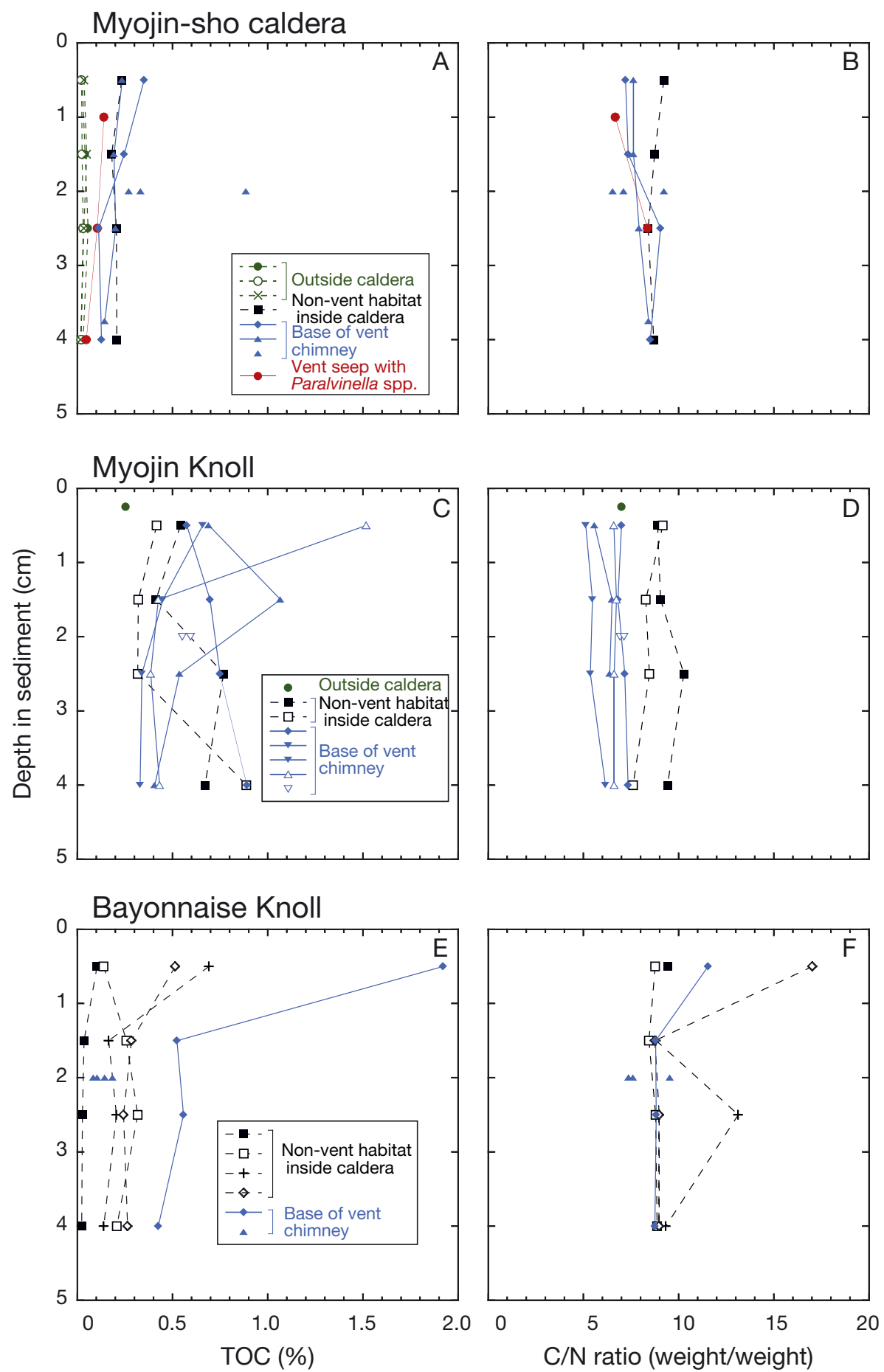

Fig. 3. Vertical profiles of total organic carbon concentration (TOC) and $\mathrm{C} / \mathrm{N}$ ratio of sediments collected from 3 habitats (outside caldera, non-vent fields inside caldera, and basal sediment of vent chimneys) of 3 submarine volcanos (Myojin-sho submarine caldera, Myojin Knoll, and Bayonnaise Knoll). The Myojin Knoll outside caldera sample was not sampled by push corer, so data are plotted at the approximate sampling depth below the sedimentwater interface. The $\mathrm{C} / \mathrm{N}$ ratios of the Myojin-sho outside caldera sample were not plotted due to lack of nitrogen data

\subsubsection{Non-vent outside caldera: reference sites}

Sediments and meiofaunal samples from outside the calderas were collected only from Myojin Knoll and the Myojin-sho caldera. The $\delta^{13} \mathrm{C}$ values of surface sediments ranged from -24.4 to $-21.1 \%$, and $\delta^{15} \mathrm{~N}$ values ranged between 0.9 and $3.2 \%$ (Table S1,
Fig. 4A,B; Setoguchi et al. 2014). All meiofauna, namely nematodes, copepods (mainly harpacticoid copepods), and isopods from Myojin Knoll, exhibited similar $\delta^{13} \mathrm{C}$ values $(-23.4$ to $-19.3 \%$ ) which are closer to surface sediments. The $\delta^{15} \mathrm{~N}$ values ranged between 8.3 and $10.8 \%$, which were enriched in ${ }^{15} \mathrm{~N}$ by roughly $7 \%$ compared to surface sediments. 

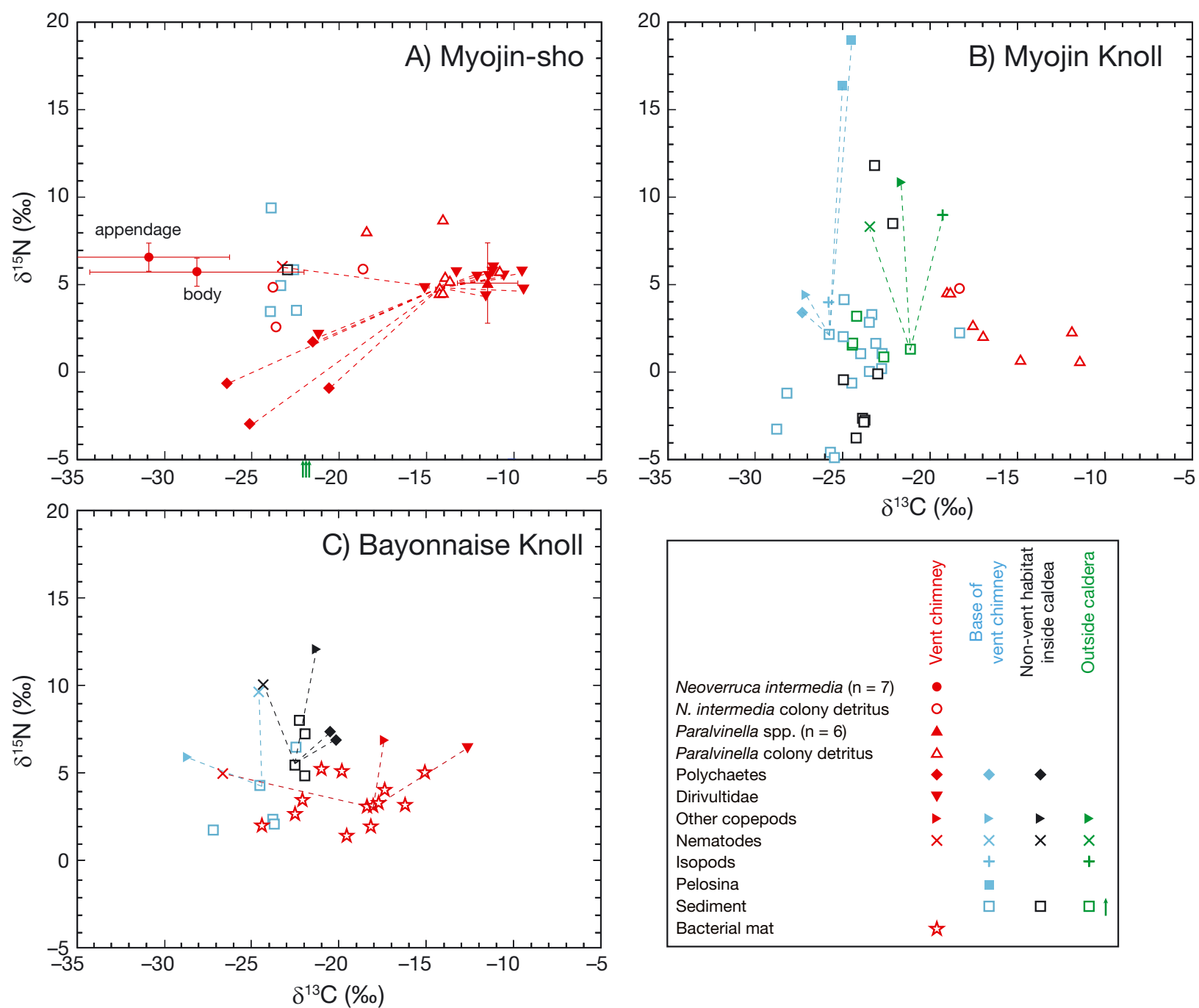

Fig. 4. Stable carbon vs. nitrogen isotopic compositions of surface sediments, bacterial mats and detritus on hydrothermal vent chimneys, and organisms, collected from (A) Myojin-sho caldera, (B) Myojin Knoll, and (C) Bayonnaise Knoll. Different colors indicate different habitats. Dashed line connects an organism with its substrate sample (sediment, detritus, or bacterial mat). Macrofaunal samples (Paralvinella spp. and Neoverruca intermedia) were plotted as mean \pm SD of 6 or 7 samples, respectively. Carbon isotopic compositions of outside caldera at Myojin-sho were plotted as green arrows on the $x$-axis because nitrogen isotopic compositions were not measured (Table S1 in the Supplement)

\subsubsection{Non-vent sediment inside caldera}

There was little variation in $\delta^{13} \mathrm{C}$ values in sediments from the non-vent area inside the calderas $(-24.9$ to $-21.9 \%)$ but more variation in $\delta^{15} \mathrm{~N}$ values (-3.8 to $11.8 \%$; Fig. 4). Despite generally similar $\delta^{15} \mathrm{~N}$ values in non-vent sediment sampled from inside calderas at the Bayonnaise Knoll and Myojin-sho (4.8 to $8.0 \%$ and $5.9 \%$, respectively), Myojin-Knoll values were mostly low $(-3.8$ to $-0.1 \%$ ) in contrast to substantially high $\delta^{15} \mathrm{~N}$ values of up to $11.8 \%$ in 2 surface sediment samples (Table S1, Fig. 4). Meiofauna from this habitat at Bayonnaise Knoll exhibited a slightly wider range in $\delta^{13} \mathrm{C}$ values $(-24.3 \%$ to $-20.1 \%$ o) than those of sediments $(-22.5 \%$ to $-21.9 \%$ ). Nematode and copepod $\delta^{15} \mathrm{~N}$ values of 10.0 and $12.0 \%$, respectively, were $\sim 5$ and $\sim 7 \%$ higher than those of isolated sediments, in contrast to $\delta^{15} \mathrm{~N}$ values being $<2 \%$ higher in polychaetes compared to isolated sediment (Fig. 4C).

\subsubsection{Basal sediment of hydrothermal vent chimneys}

The $\delta^{13} \mathrm{C}$ values in basal sediment of vent chimneys varied greatly ( -28.8 to $-18.3 \%$ o) relative to outsidecaldera and non-vent sediments (Fig. 4). Nitrogen 
isotopic composition also varied greatly, ranging from -4.9 to $9.4 \%$. Acknowledging limited numbers of replicates for meiofaunal samples, $\delta^{13} \mathrm{C}$ values from copepods ( -28.6 and $-27.1 \%)$ and polychaetes $(-27.3 \%)$ were more depleted in ${ }^{13} \mathrm{C}$ than in meiofauna from outside the caldera and non-vent sites inside calderas. The $\delta^{13} \mathrm{C}$ value from nematodes was almost identical to those from nematodes outside the caldera and from non-vent sediments (Fig. 4). The $\delta^{15} \mathrm{~N}$ values of chimney-base meiofauna ranged between 3.4 to $9.6 \%$, which were slightly lower than in other habitats. Exceptionally high $\delta^{15} \mathrm{~N}$ values (16.4 and $19.0 \%$ ) in large agglutinated foraminifera, presumably Pelosina spp., were distinct from those of metazoan meiofauna (Fig. 4B).

\subsubsection{Hydrothermal vent chimney}

The bacterial mats at Bayonnaise Knoll and detritus of Paralvinella and Neoverruca intermedia colonies collected from Myojin Knoll and Myojin-sho, which constitute the substrate habitat of meiofauna, varied widely in $\delta^{13} \mathrm{C}$ values (Fig. 4$) ;-24.4$ to $-15.1 \%$ for bacterial mat, -23.2 to $-10.8 \%$ for Paralvinella colony detritus, and -23.6 to $-18.3 \%$ for $N$. intermedia colony detritus. Relatively narrow $\delta^{15} \mathrm{~N}$-value ranges in bacterial mat or detritus samples were mostly comparable among different substrates; 1.4 to $5.1 \%$ for bacterial mats, 0.6 to $5.8 \%$ for Paralvinella colony detritus, and 2.6 to $5.9 \%$ for $N$. intermedia colony detritus.

Two vent-specific macrofauna, Paralvinella spp. and $N$. intermedia, exhibited contrasting $\delta^{13} \mathrm{C}$ values. The $\delta^{13} \mathrm{C}$ values of Paralvinella spp. ranged between -14.2 and $-8.2 \%$, whereas those of $N$. intermedia were more depleted in ${ }^{13} \mathrm{C}(-34.9$ to $-22.7 \%)$ than any other samples examined in this study (Fig. $4 \mathrm{~A}, \mathrm{~B}$ ). The $\delta^{13} \mathrm{C}$ values of dirivultids, vent-specific copepods predominantly found in Paralvinella colony samples, were similar to Paralvinella spp.: -15.1 to $-9.4 \%$, except for a single low $\delta^{13} \mathrm{C}$ value (Fig. $4 \mathrm{~A}$ ). Nematodes on the vent chimney were more depleted in ${ }^{13} \mathrm{C} \quad(-26.6$ and $-23.2 \%$ ) compared to values for isolated mats or detritus (Figs. 4A,C). As a result, similar $\delta^{13} \mathrm{C}$ ranges characterized all nematodes measured in this study at all 4 habitats, sharply contrasting the relatively large scatter in copepod and polychaete data. Benthic copepods (mainly harpacticoid copepods excluding Dirivultidae) exhibited $\delta^{13} \mathrm{C}$ values intermediate between those of Dirivultidae and nematodes (Fig. 4C), although we examined only a single sample from this habitat. An unidentified polychaete species exhibited $\delta^{13} \mathrm{C}$ values similar to nematodes, but individuals were more depleted in ${ }^{15} \mathrm{~N}(-3.0$ to $1.7 \%$ ) than any other organism (Fig. 4A).

\subsection{Natural-abundance radiocarbon}

Natural-abundance radiocarbon content clearly differed between water-column plankton and ventchimney mats or organisms (Fig. 5). Chaetognatha and Decapoda collected from a depth of $300 \mathrm{~m}$, which were $\sim 500 \mathrm{~m}$ above the Myojin-sho hydrothermal vent field, exhibited $\Delta^{14} \mathrm{C}$ values of 35 and $47 \%$, respectively, which were close to the DIC of the surface water of the adjacent area $(57 \%$, WOCE P02line, site 23; https://cchdo.ucsd.edu/search? q=p02). In contrast, vent chimney detritus and organisms where characterized by substantially depleted ${ }^{14} \mathrm{C}$ concentrations compared to those from photosynthesis-based ecosystems. The $\Delta^{14} \mathrm{C}$ values of detritus

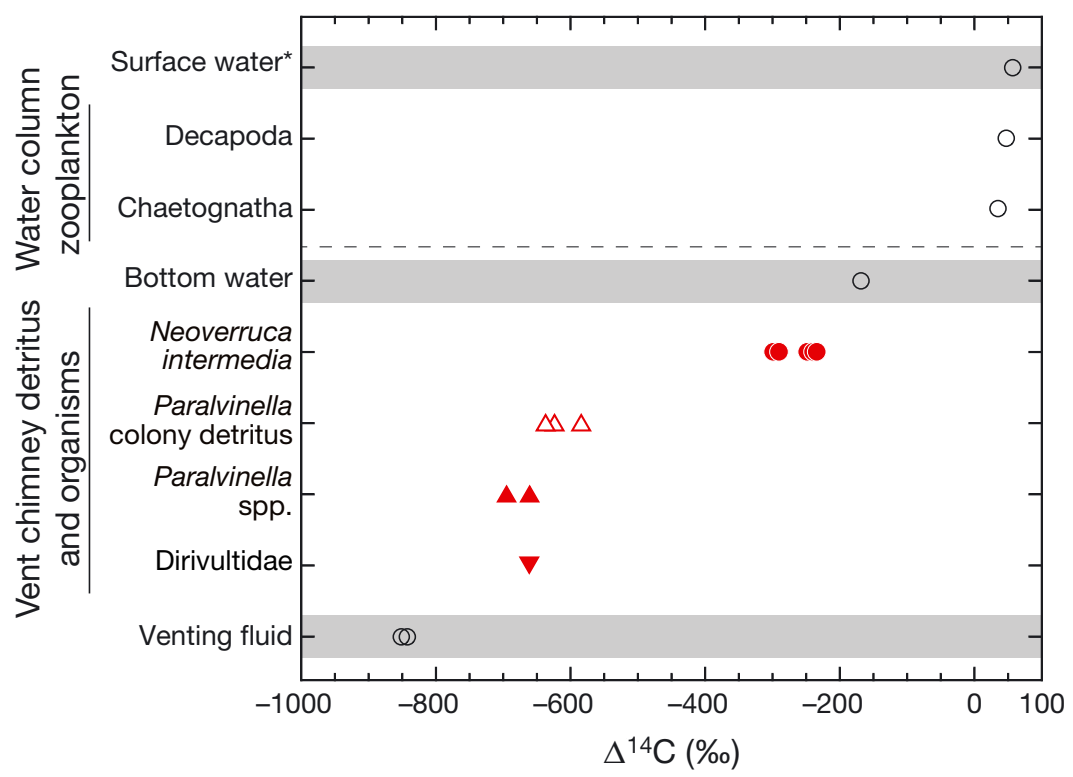

Fig. 5. Natural-abundance radiocarbon $\left(\Delta^{14} \mathrm{C}\right)$ of selected organisms and bacterial mats collected from hydrothermal vent chimneys and the adjacent water column at Myojin-sho caldera. Also plotted are $\Delta^{14} \mathrm{C}$ values from water samples collected in surface water, bottom water, and venting fluid at Myojin Knoll. The shaded values indicate DIC values, while non-shading values indicate OM samples. Dashed line separates the ocean surface values from deep-sea values. ${ }^{*}$ Surface water value reported by the WOCE project $\left(30.0^{\circ} \mathrm{N}, 139.93^{\circ} \mathrm{E}\right.$; https://cchdo.ucsd.edu/search?q=p02) 
from Paralvinella colonies varied from -636 to $-584 \%$. Paralvinella spp. and female Stygiopontius senokuchiae (Dirivultidae), which occurred on the detritus, yielded values of -695 to $-661 \%$, and $-661 \%$, respectively, and were slightly more depleted in ${ }^{14} \mathrm{C}$ than the detritus (Fig. 5). These values were intermediate between the DIC of bottom water in the area $(-168 \%)$ and venting fluid (-851 and $-842 \%$ ), but tended toward the venting fluid values.

Neoverruca intermedia collected from the vent chimneys at a lower-temperature habitat $\left(6.5-7^{\circ} \mathrm{C}\right)$ than the Paralvinella spp.-habitat temperature (Senokuchi et al. 2018) exhibited $\Delta^{14} \mathrm{C}$ values from -298 to $-236 \%$. Again, these values fell between bottom-water DIC and venting-fluid DIC, but were much closer to bottom-water DIC or water-column zooplankton values than to those of other hydrothermal vent organisms, i.e. Paralvinella and Stygiopontius (Table S4, Fig. 5). Among the 5 individuals which were examined for isotopic analyses, specimens exhibiting low $\Delta^{14} \mathrm{C}$ values tended to be enriched in ${ }^{13} \mathrm{C}$ (Table S4).

\section{DISCUSSION}

\subsection{Nutritional sources of vent organisms Paralvinella spp. and Neoverruca intermedia}

We examined $\mathrm{C}$ and $\mathrm{N}$ isotopic compositions of 2 hydrothermal vent-specific macrofauna: the polychaete Paralvinella spp. and the gastropod Neoverruca intermedia. Genus Paralvinella, abundant macrofaunal polychaetes living on the hydrothermal vent chimneys of both Myojin-sho and Myojin Knoll, are the most thermotolerant marine metazoans known (Girguis \& Lee 2006), surviving in close proximity to venting fluid and feeding on detritus on chimneys or the surface of their tubes (Grelon et al. 2006). Neoverruca intermedia likely obtain nutrition from OM produced by chemoautotrophic ectosymbionts on their exterior (Yorisue et al. 2012).

The $\delta^{13} \mathrm{C}$ values of these 2 macrofauna in our study were nearly identical to previously reports for this area (Yorisue et al. 2012). We attribute difference in $\delta^{13} \mathrm{C}$ values between these 2 species to differences in their associated microbes, which differ in carbon fixation pathways and, thus, in carbon isotopic fractionation (House et al. 2003). The $\delta^{13} \mathrm{C}$ values of $N$. intermedia, -34.9 to $-18.3 \%$, overlap the range of thioautotrophic microbes that fix either bottom water or venting fluid DIC through the CBB cycle involving RubisCO (House et al. 2003, Robinson et al. 2003), together with the $\delta^{13} \mathrm{C}$ values of bottom water and venting fluid at this site (TableS4). Methanotrophic microbes can also produce organic carbon with low $\delta^{13} \mathrm{C}$ values of about $-40 \%$. However, the substantially lower methane concentration in the present study field $(41.2 \mu \mathrm{M})$ reported by Tsunogai et al. (2000) compared to typical sediment-associated hydrothermal vent systems (Kawagucci 2015), suggests that methane is not a major $\mathrm{C}$ source for chemoautotrophic microbes in our sites. Further, the $\delta^{13} \mathrm{C}$ values of vent-fluid methane at Myojin Knoll (-17.1 to $-15.5 \%$, Tsunogai et al. 2000) were enriched in ${ }^{13} \mathrm{C}$ in comparison to Iheya North Knoll (-54.0 to $-52.8 \%$ ) and Hatoma Knoll ( -51.3 to $-44.3 \%$ ) in Okinawa Trough (Naraoka et -al. 2008, Kawagucci et al. 2011). Because the $\delta^{13} \mathrm{C}$ values of OM produced by methanotrophic microbes reflect a $\mathrm{CH}_{4}$ source, we cannot attribute the depleted $\delta^{13} \mathrm{C}$ values of $N$. intermedia to methanotrophic microbes, but rather to thioautotrophic microbial production and subsequent assimilation. Conversely, the $\delta^{13} \mathrm{C}$ values of Paralvinella spp. (-14.2 to $-8.2 \%$ ) fall within the range of rTCA-mediated carbon fixation (House et al. 2003). Similar or slightly ${ }^{13} \mathrm{C}$-enriched $\delta^{13} \mathrm{C}$ values of Paralvinella spp. compared to detritus collected from Paralvinella colonies (Fig. 4A), suggest that Paralvinella spp. utilize $\mathrm{C}$ produced by chemoautotrophic microbes.

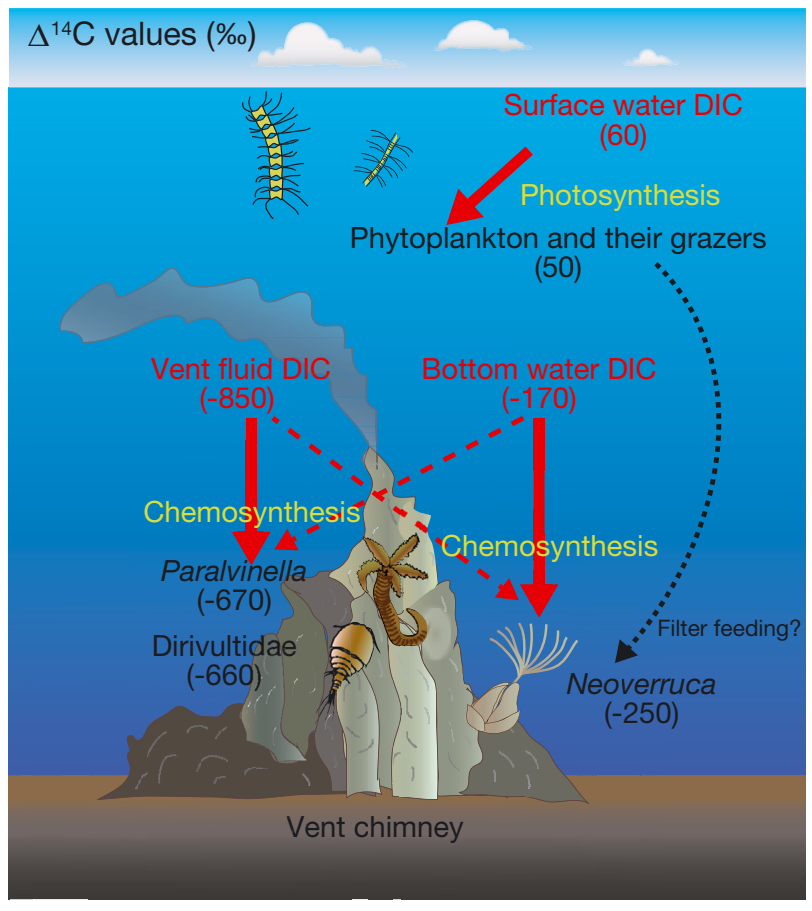

Fig. 6. Schematic illustration showing general $\Delta{ }^{14} \mathrm{C}$ values of different dissolved inorganic carbon sources and organisms measured in this study. Not to scale 
The $\Delta^{14} \mathrm{C}$ values of Paralvinella spp. and $N$. intermedia clearly demonstrated acquisition of nutrition from chemoautotrophic microbes, especially in Paralvinella spp. Also, $\Delta^{14} \mathrm{C}$ data indicate different DIC sources for these 2 taxa (Fig. 6). Paralvinella spp. $\Delta \Delta^{14} \mathrm{C}$ values from -695 to $-661 \%$ more closely resemble venting fluid values (-851 and $-842 \%$ ) than bottom water DIC $(-168 \%)$ and clearly differ from water-column zooplankton, Chaetognatha $(35 \%)$ and Decapoda $(47 \%)$, which utilize OM originating from photosynthesis (Table S4, Fig. 6). Chemoautotrophic microbes of Paralvinella colonies synthesize OM using DIC mainly originating from venting fluid, and Paralvinella spp. feed on such microbes in their habitat (Fig. 6). The $\Delta^{14} \mathrm{C}$ values of $\sim-600 \%$ in Paralvinella colony detritus containing chemoautotrophic microbes was slightly higher than in Paralvinella spp., suggesting Paralvinella spp. selectively ingests chemoautotrophic microbes from the detritus, as suggested by $\delta^{13} \mathrm{C}$ values (Fig. 4).

Natural-abundance radiocarbon values in $N$. intermedia of $\sim-300 \%$ to $-230 \%$ were relatively closer to bottom water DIC $(-168 \%$ ) than to Paralvinella spp. $(-661$ and $-695 \%)$. The $\Delta^{14} \mathrm{C}$ values of $N$. intermedia are similar to those previously reported for hydrothermal vent organisms; Riftia pachyptila (-270\%) and Bathymodiolus thermophilus (270 to $-228 \%$ ) from Galapagos hydrothermal vents (Williams et al. 1981). Slightly depleted ${ }^{14} \mathrm{C}$ values compared to in situ bottom water $(-233 \%)$ suggest a modest contribution $(4.4 \%)$ of magmatic DIC to bottom-water DIC. Distance from the vent explained differences in $\Delta^{14} \mathrm{C}$ values of $B$. thermophilus: examples collected $1 \mathrm{~m}$ from the vent had values ranging from -270 to $-254 \%$, whereas the value of $-228 \%$ for $B$. thermophilus collected $8 \mathrm{~m}$ from the vent resembled the bottom-water value. In our study, colonies of $N$. intermedia were located some 10s of $\mathrm{cm}$ further away from the active vent than Paralvinella colonies. Further distance equates to lower water temperature (Senokuchi et al. 2018), suggesting that ambient seawater at $N$. intermedia colonies contained less hydrothermal vent fluid (which contains less ${ }^{14} \mathrm{C}$ ) than that in Paralvinella colony detritus (Fig. 6). Because chemoautotrophic microbes synthetize OM using DIC in surrounding seawater, a mixture of venting fluid and bottom water, chemoautotrophic biomass in the $N$. intermedia colony detritus exhibited higher $\Delta^{14} \mathrm{C}$ values than those of Paralvinella spp. with values closer to bottom-water $\Delta^{14} \mathrm{C}$. Our findings suggest that the $\Delta^{14} \mathrm{C}$ values of symbiotic hydrothermal vent organisms reflect the differences in mixing of bottom-water DIC and hydrothermal vent fluid DIC at the decimeter to meter scale.
Another potential explanation for higher $\Delta^{14} \mathrm{C}$ values of $N$. intermedia compared to dirivultid copepods and Paralvinella spp. is that $N$. intermedia partly utilizes photosynthetic OM via filter feeding, in addition to acquiring $\mathrm{OM}$ from epibionts (Fig. 6). However, among $N$. intermedia, $\delta^{13} \mathrm{C}$ values of -34.0 to $-32.7 \%$ characterized specimens with $\Delta^{14} \mathrm{C}$ values closest to phytoplankton ecosystems (Table S4), which are indicative of a chemoautotrophic carbon contribution rather than exclusive photosynthetic OM (typically, -25 to $-20 \%$ o).

Several scenarios could explain depleted ${ }^{14} \mathrm{C}$ concentrations in deep-sea organisms: food-web transfer effects, heterotrophic DIC uptake (i.e. anaplerotic pathway), and autotrophic C-fixation using bottomwater DIC (Rau et al. 1986). None of these processes, however, can explain our very low ${ }^{14} \mathrm{C}$ concentrations $(<-600 \%)$. A $\Delta^{14} \mathrm{C}$ value $<-600 \%$ sometimes characterizes refractory DOC in seawater as a result of long turnover rates (millennial scale; Follett et al. 2014). Deep-sea benthic archaea reportedly recycle specific organic compounds such as isoprenoid (Takano et al. 2010), suggesting those compounds consist of ${ }^{14} \mathrm{C}$ depleted carbon. However, considering (1) the difficulty in utilizing refractory organic matter, (2) the minor fraction of total archaeal biomass comprised of recycled organic compounds, and (3) the sustaining of hydrothermal-vent ecosystems by chemoautotrophic $\mathrm{C}$ production, we attribute depleted $\Delta^{14} \mathrm{C}$ values in our study to the production of OM by chemoautotrophic prokaryotes using DIC in venting fluids.

\subsection{Ecology of Dirivultidae and other copepods}

The copepod family Dirivultidae may be the most successful hydrothermal vent meiofaunal taxon (Gollner et al. 2010a, 2015a). Although some hydrothermal vent macro- and megafauna also inhabit cold-seep or organic-fall habitats, Dirivultidae occur only at hydrothermal vents and their adjacent hard-rock substrates. Such distributions may relate to the strong nutritional relationships between Dirivultidae and chemoautotrophic microbial mats on the vent chimneys. Dirivultid copepods are thought to ingest bacterial mats and other detritus based on their mouthpart morphology and gut contents (Dinet et al. 1988, Heptner \& Ivanenko 2002). Lipid biomarkers and stable carbon isotopic composition further suggests that dirivultids utilize vent-chimney bacteria (Limen et al. 2008).

Similar $\delta^{13} \mathrm{C}$ and $\delta^{15} \mathrm{~N}$ values in Dirivultidae and Paralvinella spp. in our study (Fig. 4A) strongly suggest a similar nutritional source, i.e. OM produced by 
chemoautotrophic microbes. Similar $\Delta{ }^{14} \mathrm{C}$ values in Dirivultidae (-661\%) and Paralvinella spp. (-695 to $-661 \%$ ), which resembled vent fluid values (Table S4, Fig. 6), further support this possibility. These nutritional strategies are consistent with mouth-part morphology and gut content observations, which suggest they feed on vent-chimney microbes (Dinet et al. 1988, Heptner \& Ivanenko 2002). At Northeast Pacific vents, Limen et al. (2008) suggested dirivultids as a potential food source for Paralvinella based on differences in $\delta^{15} \mathrm{~N}$ values of the 2 taxa. In our study, comparable $\delta^{15} \mathrm{~N}$ values in dirivultids and Paralvinella do not support a predator-prey relationship.

Among the Dirivultidae, some vent specialist species occur solely on vent chimneys, in contrast to other hard-substrate generalists that colonize both vent chimneys and basalt around Mid-Ocean Ridge hydrothermal vents (Gollner et al. 2010b). Vent specialists likely gain nutritional benefit from the chemoautotrophs, whereas generalists living on hard substrates likely rely on different OM. Understanding distributional patterns of vent specialists and their dispersal processes requires further nutritional investigations.

Copepods other than dirivultids were mainly harpacticoids with site-specific $\delta^{13} \mathrm{C}$ signatures (Figs. 4 \& 7). Copepod $\delta^{13} \mathrm{C}$ values at the outside caldera and caldera non-vent sites $(-21.6 \%$ and $-21.3 \%$, respectively) were similar to other meiofaunal groups and bulk sediments. The $\delta^{13} \mathrm{C}$ values in copepods from vent-chimney basal sediments (-28.6 and $-27.1 \%$ ) were 2 to $4 \%$ depleted in ${ }^{13} \mathrm{C}$ relative to ambient sediments. Considering the mixture of different food sources in bulk sediment and low $\delta^{13} \mathrm{C}$ values in some vent-base sediments likely resulting from contributions of vent-produced OM (Fig. 3), copepods in vent-base sediments may selectively feed on ${ }^{13} \mathrm{C}$ depleted OM produced through chemoautotrophic carbon production with Form I RubisCO (House et al. 2003). The lower $\delta^{13} \mathrm{C}$ values $(-17.4 \%$ ) in ventchimney copepods than in dirivultids from the same habitat suggest both photosynthesis- and chemosynthesis-derived carbon contributions (Fig. 7). Although we did not speciate those copepods, diverse feeding traits likely exist where at least some use both photosynthetic and chemosynthetic OM.

\subsection{Nutritional sources of nematodes}

While our copepods apparently used a variety of nutritional sources in the various habitats, similar ranges of $\delta^{13} \mathrm{C}$ values ( -26.6 to $-23.2 \%$ ) characterized nematodes, regardless of their habitat, even for OM $\delta^{13} \mathrm{C}$ values of $\sim-10 \%$ at the vent chimney (Figs. 4 \& 7). Nematodes in our sites likely lacked strong nutritional dependence on OM produced by chemoautotrophic microbes. Previous studies on nematodes from other hydrothermal vent areas and serpentinitehosted ecosystems report $\delta^{13} \mathrm{C}$ values similar to photosynthetic OM (Bergquist et al. 2007, Limen et al. 2007, Onishi et al. 2018).
Fig. 7. Schematic illustration showing general $\delta^{13} \mathrm{C}$ values of different dissolved inorganic carbon sources and representative organisms measured in this study. Not to scale

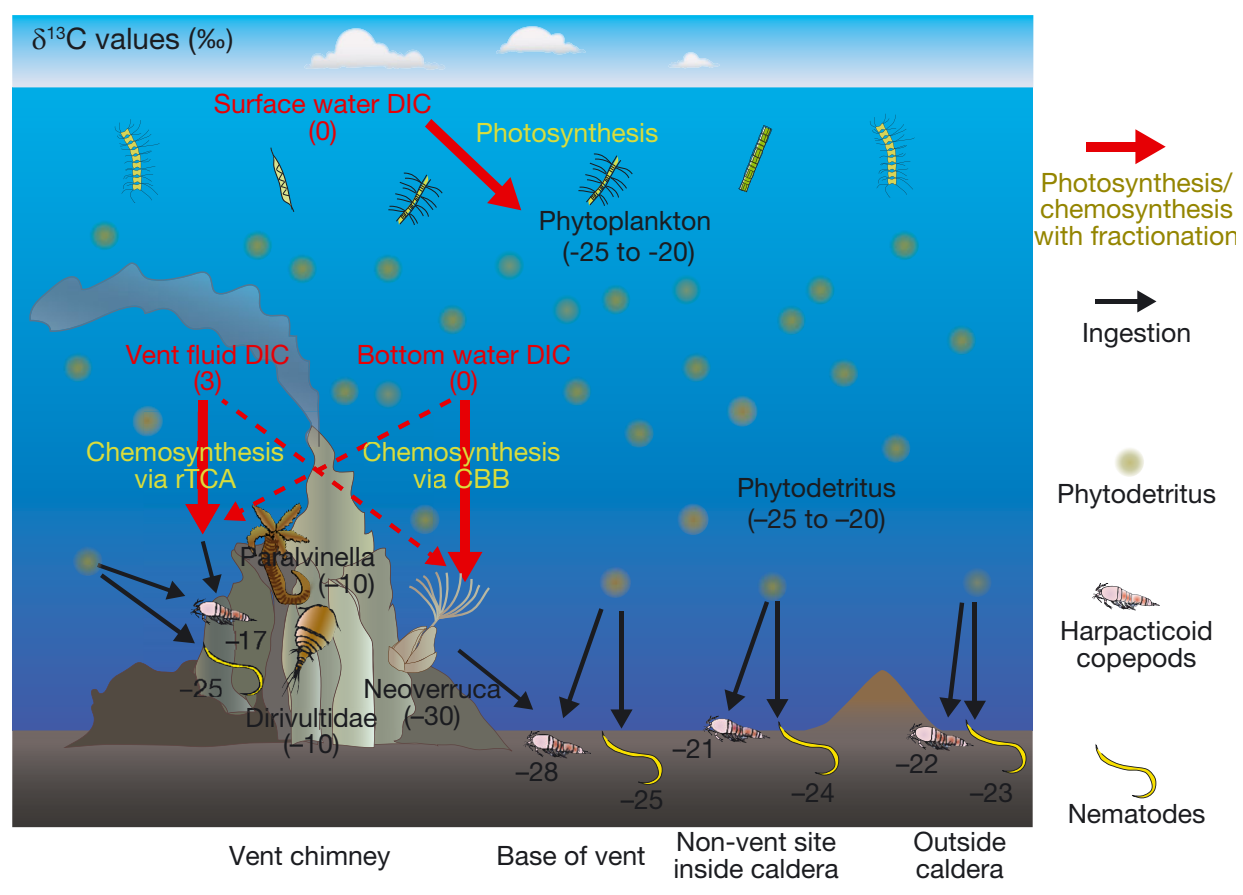


In contrast, $\delta^{13} \mathrm{C}$ values ( - $40 \%$ ) sometimes characterize nematodes from methane-seep sites, suggesting reliance on chemoautotrophic microbes or associated degraded OM in seeps (Van Gaever et al. 2006, Pape et al. 2011). These reports indicate that certain nematodes can actually obtain nutrition from chemoautotrophic microbes, at least at methaneseep sites. Differences between methane-seep and hydrothermal-vent microbial communities may explain these contrasting feeding habits in nematodes. The high temperatures of vent fluids may preclude ingestion of chemoautotrophic microbes at hydrothermal vents by nematodes. Gollner et al. (2015a) suggest that typically slower locomotion rates in nematodes than copepods make them more vulnerable to the extreme spatial and temporal variation in temperature and chemistry around vents.

Given the difficulty of suction-sampling hard substrata, our vent-chimney samples encompassed areas as long as $30 \mathrm{~cm}$. Thus, our vent-chimney nematodes might come from a 'relatively' low temperature site with depauperate chemosynthetic OM (Sweetman et al. 2013). Nematodes with $\delta^{13} \mathrm{C}$ values of $\sim-20 \%$, which are within the range of photosynthetic OM, potentially included a mixture of multiple chemoautotrophic microbes with $\delta^{13} \mathrm{C}$ values of $-30 \%$ and $-10 \%$, for example (Fig. 4A). A recent study on large (macrofaunal-sized) nematodes from a Mid-Ocean Ridge hydrothermal vent revealed the presence of sulfur-oxidizing epibionts that may be symbionts (Bellec et al. 2018). Future measurements of naturalabundance radiocarbon of nematodes should clarify whether they actually gain photosynthesis-originated carbon or a mixture of OM sources.

\subsection{Contribution of vent-detritus to the vent-base sediments}

At the base of the vent-chimney, we observed lower $\delta^{13} \mathrm{C}$ values in some cores than in outside caldera or non-vent caldera sites as low as $-27.2 \%$ (Table S1) or -28.5\% (Setoguchi et al. 2014). Copepod and polychaete $\delta^{13} \mathrm{C}$ values of -28.6 to $-27.1 \%$ were $\sim 1.5$ to $4 \%$ lower than in adjacent sediments (Tables S1 \& S2, Fig. 4). Contributions of chemoautotrophic organic carbon, such as Bathymodiolus septemdierum (-35\%; Yorisue et al. 2012) or N. intermedia biomass (on average $-30 \%$, Fig. 4) may explain these depleted $\delta^{13} \mathrm{C}$ values. The $\delta^{13} \mathrm{C}$ values of chimney-base meiofauna suggest that these organisms selectively ingest chemosynthetic OM from the sediments they inhabit (Fig. 7). High TOC and TN con- centrations and low $\delta^{13} \mathrm{C}$ values in the surface centimeter of several vent-base sediments also suggest a contribution from chemosynthetic OM (Fig. 3C,E, Table S1). Thus, chemoautotrophic carbon production at the hydrothermal vent chimney supports not only chimney-attached fauna, but also fauna living in surrounding sediments, although the effect of such OM was limited (at most several 100 m, Uejima et al. 2017) based on the geochemistry of our non-vent sediments (Table S1, Fig. 3). Also, not all the ventbase sediments showed these surface TOC peaks, implying local and/or episodic delivery of chemosynthetic OM relating to the intricate chimney structure and base bathymetry, along with temporal changes in hydrothermal-vent activity.

In basal sediments with high surface TOC concentrations (Sample ID K-BV5a in Table S1), large agglutinated foraminifera, presumably Pelosina sp., occurred in surface sediments. These protists can extend their reticulopods through and from the sediment into the overlying water column, thus potentially utilizing OM deposited from the overhanging chimney surface. However, the Pelosina sp. $\delta^{13} \mathrm{C}$ values of $\sim-25 \%$, did not substantially differ from those of non-vent sediments (Table S3, Fig. 4B). A notably high $\delta^{15} \mathrm{~N}$ (almost $19.0 \%$ ) isotopic signature characterized this organism (Table S4, Fig. 4B). The differences in $\delta^{15} \mathrm{~N}$ values between Pelosina sp. and ambient sediments (14.2 and 16.8\%; Fig. 4B) roughly correspond to a 4 to 5 trophic-level increase, assuming a typical trophic-enrichment factor of $3.4 \%$ per trophic level (Minagawa \& Wada 1984). Foraminifera from the Pakistan Margin oxygen minimum zone reportedly exhibited broad ranges of cytoplasmic $\delta^{15} \mathrm{~N}$ values; a maximum value of $27.3 \%$ was $\sim 20 \%$ o heavier than those of co-occurring bulk sediments (Jeffreys et al. 2015). Those authors speculated that the high $\delta^{15} \mathrm{~N}$ values reflected the ${ }^{15} \mathrm{~N}$-enriched intracellular nitrate pool where, perhaps, ${ }^{14} \mathrm{NO}_{3}$ was preferentially used for denitrification (e.g. Bernhard et al. 2012). Nomaki et al. (2015) further suggested that ${ }^{15} \mathrm{~N}$-enriched amino acids produced from their ${ }^{15} \mathrm{~N}$ enriched nitrate pool may explain these high $\delta^{15} \mathrm{~N}$ values of foraminiferal cells. A more complete explanation of observed high $\delta^{15} \mathrm{~N}$ values requires further data on nitrate contents and denitrification capabilities of Pelosina sp.

\section{CONCLUSIONS}

The $\Delta^{14} \mathrm{C}$ values of Paralvinella spp., dirivultid copepods and Neoverruca intermedia clearly de- 
monstrate utilization of chemoautotrophic OM produced at the hydrothermal vents. The $\Delta^{14} \mathrm{C}$ values also provide quantitative information on the DIC source of chemoautotrophs in each habitat, from highly-depleted ${ }^{14} \mathrm{C}$ concentrations in pure venting fluid DIC, to pure bottom-water DIC, and mixtures of thereof (Fig. 6). Several factors control mixing of hydrothermal vent fluid and surrounding bottom water, such as vent-fluid flux, bottom-water flow intensity, micro-topography, and distance from the vent. Close proximity of Paralvinella colonies to active venting allows Paralvinella and dirivultid copepods to obtain nutrition from chemoautotrophic bacteria that produce organic carbon using 'pure' hydrothermal vent fluids. Our $\delta^{13} \mathrm{C}$ values suggest spatial variations in food sources of harpacticoid copepods, whereas nematodes may utilize similar food sources across different habitats (Fig. 7). The combination of stable and radioisotope analyses of hydrothermal vent organisms provides valuable information regarding nutritional sources and, hence, adaptive ecology within chemosynthesis-based ecosystems.

Acknowledgments. We are grateful to the crews and scientists of the R/V 'Natsushima' and the ROV 'Hyper-Dolphin' of the Japan Agency for Marine-Earth Science and Technology (JAMSTEC) during the NT12-10, NT13-09 and NT14-06 cruises, and the R/V 'Kaimei' and the KM-ROV of JAMSTEC during the KM-ROV training cruise. We thank Yuki Iwadate for her help on sample preparations and 2 anonymous reviewers and the editor, who provided helpful comments on an earlier version of this manuscript. This work was supported by a Grant-in-Aid for Scientific Research from the Ministry of Education, Culture, Sports, Science and Technology, Japan (Scientific Research C 26440246 to M.S.), the Japan Society for the Promotion of Science (Invitational fellowships for research in Japan, S14032 to J.M.B.), the WHOI Robert W. Morse Chair for Excellence in Oceanography, and The Investment in Science Fund at WHOI.

\section{LITERATURE CITED}

Belkin S, Nelson DC, Jannasch HW (1986) Symbiotic assimilation of $\mathrm{CO}_{2}$ in two hydrothermal vent animals, the mussel Bathymodiolus thermophiles and the tube worm Riftia pachyptila. Biol Bull 170:110-121

Bell JB, Aquilina A, Woulds C, Glover AG and others (2016) Geochemistry, faunal composition and trophic structure in reducing sediments on the southwest South Georgia margin. R Soc Open Sci 3:160284

Bellec L, Cambon-Bonavita MA, Cueff-Gauchard V, Durand L, Gayet N, Zeppilli D (2018) A nematode of the MidAtlantic Ridge hydrothermal vents harbors a possible symbiotic relationship. Front Microbiol 9:2246

Bergquist DC, Eckner JT, Urcuyo IA, Cordes EE, Hourdez S, Macko SA, Fisher CR (2007) Using stable isotopes and quantitative community characteristics to determine a local hydrothermal vent food web. Mar Ecol Prog Ser 330:49-65
Bernhard JM, Casciotti KL, McIlvin MR, Beaudoin DJ, Visscher PT, Edgcomb VP (2012) Potential importance of physiologically diverse benthic foraminifera in sedimentary nitrate storage and respiration. J Geophys Res 117: G03002

Boxshall GA, Halsey SA (2004) An introduction to copepod diversity. The Ray Society, London

* Cavanaugh CM, Gardiner SL, Jones ML, Jannasch HW, Waterbury JB (1981) Prokaryotic cells in the hydrothermal vent tube worm Riftia pachyptila Jones: possible chemoautotrophic symbionts. Science 213:340-342

* Copley JTP, Flint HC, Ferrero TJ, Van Dover CL (2007) Diversity of meiofauna and free-living nematodes in hydrothermal vent mussel beds on the northern and southern East Pacific Rise. J Mar Biol Assoc UK 87:1141-1152

Dinet A, Grassle F, Tunnicliffe V (1988) Premières observations sur la méiofaune des sites hydrothermaux de la dorsale Est-Pacifique (Guayamas, $21^{\circ} \mathrm{N}$ ) et de $1^{\prime}$ Explorer Ridge. Oceanol Acta 8:7-14

* Duperron S, Bergin C, Zielinski F, Blazejak A and others (2006) A dual symbiosis shared by two mussel species, Bathymodiolus azoricus and Bathymodiolus puteoserpentis (Bivalvia: Mytilidae), from hydrothermal vents along the northern Mid-Atlantic Ridge. Environ Microbiol 8:1441-1447

Enge AJ, Wanek W, Heinz P (2018) Preservation effects on isotopic signatures in benthic foraminiferal biomass. Mar Micropaleontol 144:50-59

Felbeck $\mathrm{H}$ (1985) $\mathrm{CO}_{2}$ fixation in the hydrothermal vent tube worm Riftia pachyptila (Jones). Physiol Zool 58:272-281

*Fisher CR, Childress JJ, Minnich E (1989) Autotrophic carbon fixation by the chemoautotrophic symbionts of Riftia pachyptila. Biol Bull 177:372-385

Follett CL, Repeta DJ, Rothman DH, Xu L, Santinelli C (2014) Hidden cycle of dissolved organic carbon in the deep ocean. Proc Natl Acad Sci USA 111:16706-16711

* Gebruk A, Chevaldonné P, Shank T, Lutz RA, Vrijenhoek R (2000) Deep-sea hydrothermal vent communities of the Logatchev area $\left(14^{\circ} 45^{\prime} \mathrm{N}\right.$, Mid-Atlantic Ridge): diverse biotopes and high biomass. J Mar Biol Assoc UK 80:383-393

Giere O (2009) Meiobenthology. The microscopic motile fauna of aquatic sediments, 2nd ed. Universität Hamburg

Girguis PR, Lee RW (2006) Thermal preference and tolerance of alvinellids. Science 312:231

*Gollner S, Ivanenko VN, Arbizu PM, Bright M (2010a) Advances in taxonomy, ecology, and biogeography of Dirivultidae (Copepoda) associated with chemosynthetic environments in the deep sea. PLOS ONE 5:e9801

Gollner S, Riemer B, Arbizu PM, Bris NL, Bright M (2010b) Diversity of meiofauna from the $9^{\circ} 50^{\prime} \mathrm{N}$ East Pacific Rise across a gradient of hydrothermal fluid emissions. PLOS ONE 5:e12321

Gollner S, Govenar B, Fisher CR, Bright M (2015a) Size matters at deep-sea hydrothermal vents: different diversity and habitat fidelity patterns of meio- and macrofauna. Mar Ecol Prog Ser 520:57-66

Gollner S, Govenar B, Arbizu PM, Mills S and others (2015b) Differences in recovery between deep-sea hydrothermal vent and vent-proximate communities after a volcanic eruption. Deep Sea Res I 106:167-182

*Grelon D, Morineaux M, Desrosiers G, Juniper SK (2006) Feeding and territorial behavior of Paralvinella sulfincola, a polychaete worm at deep-sea hydrothermal vents of the Northeast Pacific Ocean. J Exp Mar Biol Ecol 329: 174-186 
Heptner MV, Ivanenko VN (2002) Copepoda (Crustacea) of hydrothermal ecosystems of the World Ocean. Arthropoda Sel 11:117-134

Higgins RP, Thiel H (1988) Introduction to the study of meiofauna. Smithsonian Institution Press, Washington, DC

Honsho C, Ura T, Kim K, Asada A (2016) Postcaldera volcanism and hydrothermal activity revealed by autonomous underwater vehicle surveys in Myojin Knoll caldera, IzuOgasawara arc. J Geophys Res Solid Earth 121: 4085-4102

House CH, Schopf JW, Stetter KO (2003) Carbon isotopic fractionation by Archaeans and other thermophilic prokaryotes. Org Geochem 34:345-356

' Iizasa K (1993) Assessment of the hydrothermal contribution to seafloor sediments in the Myojinsho submarine caldera, Shichito-Iwojima ridge, Izu-Ogasawara arc, Japan. Mar Geol 114:119-132

Jeffreys RM, Fisher EH, Gooday AJ, Larkin KE, Billett DSM, Wolff GA (2015) The trophic and metabolic pathways of foraminifera in the Arabian Sea: evidence from cellular stable isotopes. Biogeosciences 12:1781-1797

Kawagucci S (2015) Fluid geochemistry of high-temperature hydrothermal fields in the Okinawa Trough. In: Ishibashi J, Okino K, Sunamura M (eds) Subseafloor biosphere linked to hydrothermal systems: TAIGA concept. Springer Japan, Tokyo, p 387-403

Kawagucci S, Chiba H, Ishibashi J, Yamanaka T and others (2011) Hydrothermal fluid geochemistry at the Iheya North field in the mid-Okinawa Trough: implication for origin of methane in subseafloor fluid circulation systems. Geochem J 45:109-124

Kawagucci S, Ueno Y, Takai K, Toki T and others (2013) Geochemical origin of hydrothermal fluid methane in sediment-associated fields and its relevance to the geographical distribution of whole hydrothermal circulation. Chem Geol 339:213-225

Levin LA, Mendoza GF, Konotchick T, Lee R (2009) Macrobenthos community structure and trophic relationships with inactive and inactive Pacific hydrothermal sediments. Deep Sea Res II 56:1632-1648

Levin LA, Baco AR, Bowden DA, Colaco A and others (2016) Hydrothermal vents and methane seeps: rethinking the sphere of influence. Front Mar Sci 3:72

Limen H, Juniper SK, Tunnicliffe V, Clement M (2006) Benthic community structure on two peaks of an eruptive seamount: Northwest Rota-1 Volcano, Mariana Arc, western Pacific. Cah Biol Mar 47:457-463

Limen H, Levesque C, Juniper SK (2007) POM in macro/meiofaunal food webs associated with three flow regimes at deep-sea hydrothermal vents on Axial Volcano, Juan de Fuca Ridge. Mar Biol 153:129-139

Limen H, Stevens CJ, Bourass Z, Juniper SK (2008) Trophic ecology of siphonostomatoid copepods at deep-sea hydrothermal vents in the northeast Pacific. Mar Ecol Prog Ser 359:161-170

Markert S, Arndt C, Felbeck H, Becher D and others (2007) Physiological proteomics of the uncultured endosymbiont of Riftia pachptila. Science 315:247-250

Minagawa M, Wada E (1984) Stepwise enrichment of ${ }^{15} \mathrm{~N}$ along food chains: further evidence and the relation between $\delta^{15} \mathrm{~N}$ and animal age. Geochim Cosmochim Acta 48:1135-1140

Nakajima R, Yamamoto H, Kawagucci S, Takaya Y and others (2015) Post-drilling changes in seabed landscape and megabenthos in a deep-sea hydrothermal system, the Iheya North field, Okinawa Trough. PLOS ONE 10: e0123095

“Naraoka H, Naito T, Yamanaka T, Tsunogai U, Fujikura K (2008) A multi-isotope study of deep-sea mussels at three different hydrothermal vent sites in the northwestern Pacific. Chem Geol 255:25-32

Nomaki H, Ogawa NO, Ohkouchi N, Suga H and others (2008) Benthic foraminifera as trophic links between phytodetritus and benthic metazoans: carbon and nitrogen isotopic evidence. Mar Ecol Prog Ser 357:153-164

Nomaki H, Ogawa NO, Takano Y, Suga H, Ohkouchi N, Kitazato H (2011) Differing utilization of glucose and algal particulate organic matter by deep-sea benthic organisms of Sagami Bay, Japan. Mar Ecol Prog Ser 431: $11-24$

Nomaki H, Chikaraishi Y, Tsuchiya M, Toyofuku T and others (2015) Variation in the nitrogen isotopic composition of amino acids in benthic foraminifera: implications for their adaptation to oxygen-depleted environments. Limnol Oceanogr 60:1906-1916

Ogawa NO, Nagata T, Kitazato H, Ohkouchi N (2010) Ultrasensitive elemental analyzer/isotope ratio mass spectrometer for stable nitrogen and carbon isotope analyses. In: Ohkouchi N, Tayasu I, Koba K (eds) Earth, life and isotopes. Kyoto University Press, Kyoto, p 339-353

Onishi Y, Yamanaka T, Okumura T, Kawagucci S, Watanabe HK, Ohara Y (2018) Evaluation of nutrient and energy sources of the deepest known serpentinite-hosted ecosystem using stable carbon, nitrogen, and sulfur isotopes. PLOS ONE 13:e0199000

Pape E, Bezerra TN, Vanneste H, Heeschen K and others (2011) Community structure and feeding preference of nematodes associated with methane seepage at the Darwin mud volcano (Gulf of Cadiz). Mar Ecol Prog Ser 438: 71-83

Pearson A, McNichol AP, Schneider RJ, von Reden KF (1998) Microscale AMS ${ }^{14} \mathrm{C}$ measurement at NOSAMS. Radiocarbon 40:61-76

*Pearson A, Seewald JS, Eglinton TI (2005) Bacterial incorporation of relict carbon in the hydrothermal environment of Guaymas Basin. Geochim Cosmochim Acta 69: 5477-5486

Rau GH (1981) Hydrothermal vent clam and tube worm ${ }^{13} \mathrm{C} /{ }^{12} \mathrm{C}$ : further evidence of nonphotosynthetic food sources. Science 213:338-340

* Rau GH, Karl DM, Carney RS (1986) Does inorganic carbon assimilation cause ${ }^{14} \mathrm{C}$ depletion in deep-sea organisms? Deep-Sea Res 33:349-357

Rex MA, Etter RJ, Morris JS, Crouse J and others (2006) Global bathymetric patterns of standing stock and body size in the deep-sea benthos. Mar Ecol Prog Ser 317:1-8

Riekenberg PM, Carney RS, Fry B (2016) Trophic plasticity of the methanotrophic mussle Bathymodiolus childressi in the Gulf of Mexico. Mar Ecol Prog Ser 547:91-106

* Robinson JJ, Scott KM, Swanson ST, O'Leary MH, Horken K, Tabita R, Cavanaugh CM (2003) Kinetic isotope effect and characterization of form II RubisCO from the chemoautotrophic endosymbionts of the hydrothermal vent tubeworm Riftia pachyptila. Limnol Oceanogr 48:48-54

Rouse GW, Pleijel F (2001) Polychaetes. Oxford University Press, Oxford

Schmidt C, Lins L, Brandt A (2018) Harpacticoida (Crustacea, Copepoda) across a longitudinal transect of the Vema Fracture Zone and along a depth gradient in the Puerto Rico trench. Deep Sea Res II 148:236-250 
Senokuchi R, Nomaki H, Watanabe HK, Kitahashi T, Ogawa NO, Shimanaga M (2018) Chemoautotrophic food availability influences copepod assemblage composition at deep hydrothermal vent sites within sea knoll calderas in the northwestern Pacific. Mar Ecol Prog Ser 607:37-51

Setoguchi Y, Nomaki H, Kitahashi T, Watanabe H, Inoue K, Ogawa NO, Shimanaga M (2014) Nematode community composition in hydrothermal vent and adjacent non-vent fields around Myojin Knoll, a seamount on the IzuOgasawara Arc, in the western North Pacific Ocean. Mar Biol 161:1775-1785

Soto LA (2009) Stable carbon and nitrogen isotopic signatures of fauna associated with the deep-sea hydrothermal vent system of Guaymas Basin, Gulf of California. Deep Sea Res II 56:1675-1682

Stuiver M, Polach HA (1977) Discussion: Reporting of ${ }^{14} \mathrm{C}$ data. Radiocarbon 19:355-363

Stuiver M, Quay PD, Ostlund HG (1983) Abyssal water carbon-14 distribution and the age of the world oceans. Science 219:849-851

Sweetman AK, Levin LA, Rapp HT, Schandler C (2013) Faunal trophic structure at hydrothermal vents on the southern Mohn's Ridge, Arctic Ocean. Mar Ecol Prog Ser 473: 115-131

Takano Y, Chikaraishi Y, Ogawa NO, Nomaki H and others (2010) Sedimentary membrane lipids recycled by deepsea benthic archaea. Nat Geosci 3:858-861

Tayasu I, Hirasawa R, Ogawa NO, Ohkouchi N, Yamada K (2011) New organic reference materials for carbon- and nitrogen-stable isotope ratio measurements provided by the Center for Ecological Research, Kyoto University, and Institute of Biogeosciences, Japan Agency for MarineEarth Science and Technology. Limnology 12:261-266

Tsunogai U, Yoshida N, Ishibashi J, Gamo T (2000) Carbon isotopic distribution of methane in deep-sea hydrothermal plume, Myojin Knoll Caldera, Izu-Bonin arc: implications for microbial methane oxidation in the oceans and applications to heat flux estimation. Geochim Cosmochim Acta 64:2439-2452

Turekian KK, Cochran JK, Nozaki Y (1979) Growth rate of a clam from the Galapagos Rise hot spring field using natural radionuclide ratios. Nature 280:385-387

Uejima Y, Nomaki H, Senokuchi R, Setoguchi Y, Kitahashi T, Watanabe HK, Shimanaga M (2017) Meiofaunal com-

Editorial responsibility: Paul Snelgrove, St. John's, Newfoundland and Labrador, Canada munities in hydrothermal vent and proximate non-vent habitats around neighboring seamounts on the Izu-Ogasawa Arc, western North Pacific Ocean. Mar Biol 164:183

* Uyeno D, Watanabe HK, Shimanaga M (2018) A new dirivultid copepod (Siphonostomatoida) from hydrothermal vent fields of the Izu-Bonin Arc in the North Pacific Ocean. Zootaxa 4415:381-389

*Van Gaever S, Moodley L, de Beer D, Vanreusel A (2006) Meiobenthos at the Arctic Håkon Mosby Mud Volcano, with a parental-caring nematode thriving in sulphiderich sediments. Mar Ecol Prog Ser 321:143-155

*Vanreusel A, Bossche IV, Thiermann F (1997) Free-living marine nematodes from hydrothermal sediments: similarities with communities from diverse reduced habitats. Mar Ecol Prog Ser 157:207-219

Vanreusel A, De Groote A, Gollner S, Bright M (2010) Ecology and biogeography of free-living nematodes associated with chemosynthetic environments in the deep sea: A review. PLOS ONE 5:e12449

Watanabe H, Kojima S (2015) Vent fauna in the Okinawa Trough. In: Ishibashi J, Okino K, Sunamura M (eds) Subseafloor biosphere linked to global hydrothermal systems: TAIGA concept. Springer, Tokyo, p 449-459

Watanabe H, Fujikura K, Kojima S, Miyazaki J, Fujiwara Y (2010) Japan: Vent and seeps in close proximity. In: Kiel $\mathrm{S}$ (ed) The vent and seep biota. Springer, New York, NY, p 379-402

*Watsuji T, Yamamoto A, Takaki Y, Ueda K, Kawagucci S, Takai K (2014) Diversity and methane oxidation of active epibiotic methanotrophs on live Shinkaia crosnieri. ISME J 8:1020-1031

*Williams PM, Smith KL, Druffel EM, Linick TW (1981) Dietary carbon sources of mussels and tubeworms from Galapagos hydrothermal vents determined from tissue ${ }^{14} \mathrm{C}$ activity. Nature 292:448-449

* Yokoyama Y, Koizumi M, Matsuzaki H, Miyairi Y, Ohkouchi N (2010) Developing ultra small-scale radiocarbon sample measurement at the University of Tokyo. Radiocarbon 52:310-318

Forisue T, Inoue K, Miyake H, Kojima S (2012) Trophic structure of hydrothermal vent communities at Myojin Knoll and Nikko Seamount in the northwestern Pacific: implications for photosynthesis-derived food supply. Plankton Benthos Res 7:35-40

Submitted: December 10, 2018; Accepted: April 29, 2019 Proofs received from author(s): July 11, 2019 